\title{
Federal Preemption of State Law Under the Employee Retirement Income Security Act of 1974
}

\author{
James D. Hutchinson† \\ David M. Ifshin †† $^{-}$
}

Congress enacted the Employee Retirement Income Security Act $^{1}$ ("ERISA") in response to a perceived need for a uniform and manageable solution to a problem of national magnitude and character. The restructuring of employee compensation from the basic payment of cash wages to complex agreements of deferred compensation and casualty coverage ${ }^{2}$ presented a new dilemma in labormanagement and employee relations: to provide reasonable assurances that promised benefits would be available when due. In addressing this issue, ERISA created a comprehensive regulatory scheme directed at the displacement of state regulation of employee benefit plans.

Determining the scope of ERISA's preemption of state law has been a recurring problem in cases where state law purports to govern some aspect of employee benefit plans. Questions of the extent of federal preemption under ERISA necessarily implicate larger issues concerning the proper relationship between state and federal law. These questions have always been central in the continuing debate over the nature of American federalism; ${ }^{3}$ they are particularly relevant in this context since ERISA was enacted during a time of renewed concern with the balance of state and federal power. ${ }^{4} \mathrm{Al}-$ though the following discussion will briefly address the general issue of federal preemption, the article's focus is on the specific problems that have arisen with respect to preemption of state law by ERISA. We conclude that Congress intended to preempt almost all state

$\uparrow$ Member of the District of Columbia and Pennsylvania Bars.

t† Member of the District of Columbia and California Bars.

${ }^{1}$ Pub. L. No. 93-406, 88 Stat. 829 (codified at 29 U.S.C. $\S \S 1001-1381$ (1976)) [hereinafter cited without cross-reference as ERISA].

2 See R. McCaffery, Managing the Employee Beneftss Program 7-17 (1972).

3 The scope of the clauses of the Constitution empowering Congress to make all laws "necessary and proper" for executing its delegated powers, U.S. CONST. art. I, § 8, and declaring such federal enactments to be the "supreme law of the land," $i d$. , art. VI, were, in the words of Alexander Hamilton, "the source of much virulent invective and petulant declamation" against ratification. The FederaLIST No. 33 (A. Hamilton) 244 (B. Wright ed. 1961).

- See, e.g., Note, The Preemption Doctrine: Shifting Perspectives on Federalism and the Burger Court, 75 Colum. L. Rev. 623 (1975). 
regulation of employee pension and welfare benefit plans, but that courts have often defined the scope of preemption more narrowly where preemption may create what appear to be undesirable regulatory lacunae or supersede state law in fields traditionally left to state governance. We argue that this continued whittling away of the preemptive reach of ERISA seriously threatens the regulatory scheme devised by Congress, and that it is up to Congress, not the courts, to narrow ERISA's preemption of state law where particular policy reasons make such action appropriate.

Part I of the article discusses the history of federal regulation of employee benefit plans and outlines the substantive provisions of ERISA. Part II discusses preemption in general and under ERISA. The following three parts focus upon the three interpretive issues that, to date, have most often been raised in judicial decisions concerning the scope of preemption under ERISA: the definition of an "employee benefit plan" covered by ERISA, the question of which state laws are preempted because they "relate to" such a plan, and the interpretation of the scope of the exceptions that Congress wrote into ERISA's preemption provisions. The article then briefly examines the closely related question whether federal regulation of employee pension plans under the National Labor Relations Act preempts state regulation of such plans. Finally, Part VII discusses current proposals for legislative reform of ERISA.

\section{The Employee Retirement Income Security Act of 1974}

The first pension plan in the United States was established in $1875 ;^{5}$ the use of such employee benefit plans has increased ever since. ${ }^{6}$ The most rapid growth of private pension plans, however, has been a recent phenomenon. By the end of World War II, private pension plans covered over 6.4 million workers and controlled over $\$ 5.4$ billion in assets; ${ }^{7}$ at the end of 1977 , the assets of private, noninsured pension funds totaled approximately $\$ 181.5$ billion. ${ }^{8}$ Although employee benefit plans-collectively and individually-came to control massive amounts of capital, their rapid prolif-

5 D. Rothman, Establishing and Administering Pension and Proftr-Sharing Plans and. Trust Funds 1 (1967) (the plan was established by the American Express Company).

- See generally D. McGill, Fundamentals of Private Pensions 21-28 (1964); Norman, Private Pensions: A Study of Vesting, Funding, and Integration, 21 U. FLA. L. REv. 141, 14243 (1968).

7 D. Holland, Private Pension Funds: Projected Growth 2 (1966). See also Pfenningstorf \& Kimball, Employee Legal Service Plans: Conflicts Between Federal and State Regulation, 1976 Am. B. Foundation Research J. 787, 787-88.

37 SEC Statistical Bull., May, 1978, at 6-7. Assets of all private and public pension funds were estimated to be $\$ 501.5$ billion. Id. at 8 . 
eration was not accompanied by a corresponding development in applicable law. ${ }^{9}$ Regulation generally was confined to state law: law developed through decisions and statutes ${ }^{10}$ not uniquely adapted to providing protection for participants in such plans. Growing awareness of employee benefit plan abuses and failures revealed the inadequacy of local regulation of plans that were frequently multistate or national in scope. ${ }^{11}$ After several intermediate federal regulatory schemes, Congress enacted ERISA ${ }^{12}$ to provide comprehensive protection to participants in employee benefit plans. The need for ERISA's broadly, preemptive framework can be understood only against the background of prior regulation of employee benefit plans.

\section{A. Regulation Before ERISA}

1. Trust Law. The method frequently chosen to protect beneficiaries of employee benefit plans was the trust mechanism, ${ }^{13}$ a device traditionally committed to state governance. Alternatively, employers might pay premiums to an insurance carrier that would then become directly responsible for the provision of benefits. ${ }^{14} \mathrm{In}$ surance regulation is also an area traditionally committed to regulation by state law. Prior to ERISA, therefore, pension and welfare benefit plans were regulated by either the trust law of individual states or state insurance regulations. ${ }^{15}$

Local regulation of multistate plans has inherent disadvantages. ${ }^{18}$ The very flexibility that made trust law adaptable to the needs of employee benefit plans was also an important drawback to its value as a regulatory scheme. The law of trusts, which has as a principal purpose the administration of estates, allows trustees considerable freedom to shape the trusts they create and leaves policing to ordinary judicial processes begun by trustees, fiduciaries, or beneficiaries. Under state law, the terms of the trust agreement gener-

- See Pfenningstorf \& Kimball, supra note 7, at 788.

" G. Bogert \& G. Bogert, Law of Trusts \& Trusters $\$ 7$ (2d ed. 1965).

"See generally U.S. Dep'T of Treasury \& U.S. Dep'T of Labor, Study of Pension Plan Terminations (1973) [hereinafter cited as JoInt STUDY].

12 Pub. L. No. 93-406, 88 Stat. 829 (codified at 29 U.S.C. $\$ \S 1001-1381$ (1976)).

is Labor Management Relations (Taft-Hartley) Act of $1947 \S 302(c)(5), 29$ U.S.C. $\S$ 186(c)(5) (1976).

"See text and notes at notes 138 \& 149 infra.

is S. REP. No. 1150, 92d Cong., 2d Sess. 5 (1972); Herbert, Investment Regulation and Conflicts of Interest in Employer-Managed Pension Plans, 17 B.C. Indus. \& CoM. L. Rev. 127, 143 (1976).

1s See note 11 supra. 
ally control, ${ }^{17}$ exculpatory clauses generally are effective,,$^{18}$ common law standards of prudence do not override contrary provisions in the plan documents, ${ }^{19}$ participants and beneficiaries are not entitled to routine affirmative disclosure of detailed information about their plans, and access to the courts can be costly and time consuming. The law of trusts was thus ill-equipped to govern the complexities of welfare and pension benefit plans.

2. Federal Legislation. The earliest federal intervention in the regulation of employee benefit plans came through the income tax laws. Two kinds of questions have been involved: first, whether contributions by employers, employees, or both, should be taxed as income to the employee or taxation deferred until the benefits are distributed; second, whether employer contributions should be deductible by the employer when made or only-if at all-when distributed. The second question has been particularly relevant to the problem of regulation because congressional taxation policy has allowed immediate deduction of contributions only if made to a "taxqualified" fund, one that does not remain completely under the employer's control and is therefore not a potential tax-avoidance device.

Prior to 1921, reasonable payments to retired employees were deductible as an ordinary and necessary business expense if the total compensation given the employee remained reasonable, but the tax laws did not regulate pension plans as such. The Revenue Acts of $1921,{ }^{20} 1926,{ }^{21} 1928,{ }^{22} 1938,{ }^{23}$ and $1942^{24}$ gradually created a special regime for "qualified" plans that permitted beneficiaries to defer taxation of employers' pension fund contributions until the time of distribution. The Internal Revenue Code of 1954 represented Congress's most extensive use of the revenue laws to regulate employee benefit plans. Section $401(a)^{25}$ sets forth a series of specific requirements for a plan to be "tax qualified." The plan must be intended for the exclusive benefit of employees and their

17 Restatement (Second) of Trusts $§ 164$ (1959).

${ }_{18}$ Id. $\S 222$. See S. Rep. No. 127, 93d Cong., 1st Sess. 5 (1973), reprinted in 1 Subcomm. on Labor of the Senate Comm. on Labor and Public Welfare, 94th Cong., 2d Sess., Legislative History of the Employee Retirement Income Security ACt of 1974, at 615 (1976) [hereinafter cited as LEgISLATIVE HistoRY of ERISA].

1" Restatement (Second) of Trusts $§ 222$ (1959). See S. Rep. No. 127, supra note 18, at 29.

${ }^{20}$ Ch. 136, § 219, 42 Stat. 227, 246 (1921).

2t Ch. 27, $\$ 219$, 44 Stat. 9, 32 (1926).

22 Ch. 852, § 165, 45 Stat. 791, 839 (1928).

a Ch. 289, $\$ 165,52$ Stat. 447,518 (1938).

2 Ch. $619, \S 162,56$ Stat. 798, 862 (1942).

${ }^{23}$ I.R.C. § 401(a). 
beneficiaries, ${ }^{28}$ it may not discriminate in favor of shareholders, officers or highly compensated employees, ${ }^{27}$ it must cover a minimum percentage of all employees, ${ }^{28}$ and it must meet minimum vesting and termination rules. ${ }^{29}$ Once an employer's plan is "qualified," the employer may take immediate deductions for contributions to the plan,$^{30}$ while the employee-participant (or his beneficiary) may defer taxation of the proceeds until actually received. .1 $^{31}$

In 1947, Congress enacted the first important piece of nontax legislation relating to pension plans: the Taft-Hartley amendments to the Labor-Management Relations Act" ("LMRA"). Congress was not primarily concerned with pension plans as such, but rather sought to remedy a variety of labor-management problems, including what it perceived as abuses and corruption in labor unions. Section 302 of LMRA $^{33}$ required that unions maintaining employee benefit plans hold contributed funds in trust, ${ }^{34}$ that the use of both principal and income of the funds be restricted to the benefit of the employees and their families, ${ }^{35}$ that the funds be jointly administered by equal numbers of representatives of management and labor pursuant to a written plan, ${ }^{36}$ and that pension funds be kept in a separate pension trust segregated from other benefit trusts. ${ }^{37}$

Regulation through the Internal Revenue Code and LMRA proved inadequate in several respects. LMRA covered only certain plans in unionized industries and imposed only a few specific requirements. The Internal Revenue Code provided more protection, but could be avoided by employers willing to forego the tax benefits accompanying "tax-qualified" plans. Most importantly, neither LMRA nor the Revenue Code provided more than rudimentary tools for the enforcement of fiduciary obligations against persons in control of employee benefit plans.

In 1958, Congress finally enacted legislation dealing exclusively with employee benefit plans. By this time, almost 80 million persons

2" Id. $\$$ 401(a)(2). The IRS has construed the "exclusive benefit" rule liberally, permitting plans wide latitude in determining recipients of plan benefits.

nId. $\$ 401(\mathrm{a})(4)$.

2 Id. $\$ 401(\mathrm{a})(3)$.

2Id. $\S 401(\mathrm{a})(7)-(8)$.

* Id. $\S 404(\mathrm{a})(1)$.

sI Id. $\$ 402(a)(1)$. Additionally, income to the beneficiary may, in some circumstances, be taxed at more favorable capital gains rates. Id. $\S 402(\mathrm{a})(2)$.

32 Pub. L. No. 80-101, \& 302, 61 Stat. 157 (1947).

29 U.S.C. $\$ 186$ (1976).

s Id. § $186(\mathrm{c})(5)(\mathrm{A})$.

ss Id.

4 Id. § 186(c)(5)(B).

${ }^{37}$ Id. § 186(c)(5)(C). 
were covered by over one million plans holding assets of approximately $\$ 30$ billion. ${ }^{38}$ Weighing the financial burdens imposed by the administrative requirements of a regulatory program against the need to protect plan beneficiaries, Congress decided to rely on disclosure and reporting to reveal improprieties and to continue to depend on state law for substantive regulation. In recommending enactment of the Welfare and Pension Plan Disclosure Act of $1958^{39}$ ("WPPDA"), the House Committee on Education and Labor made clear the limited federal role intended under this act:

[WPPDA] is designed to place the primary responsibility for the policing and improved operations of these plans upon the participants and beneficiaries themselves, with a minimum of interference in the natural development and operation of such plans, reserving to the States the detailed regulations relating to insurance and trusts, and other phases of their operations, and to place the least possible burden by way of cost and otherwise upon the plans and the taxpayers in general..$^{40}$

The federal role under WPPDA was limited to requiring disclosure and filing of information. The Act required administrators ${ }^{41}$ of plans with twenty-five or more participants to publish ${ }^{42}$ and file with the Secretary of Labor ${ }^{43}$ a description of the plan with information on plan administration, benefit schedules, sources of financing, relationship-if any-to a collective bargaining agreement, and claims procedures. ${ }^{44}$ Additionally, plans with 100 or more participants were required to publish and file annual reports disclosing amounts contributed by each employer, amounts of benefits paid, a statement of assets specifying the form in which they were held, and costs of plan administration..$^{45}$ Aside from these specific provisions, as the Supreme Court stressed in Malone v. White Motor Corp., " "[WPPDA] together with the legislative history of the 1958

\& H.R. REP. No. 2283, 85th Cong., 2d Sess. 8 (1958), reprinted in [1958] U.S. Code Cong. \& Ad. News 4181, 4187. The growth of benefit trusts has been spurred by the decision of the Seventh Circuit in Inland Steel Co. v. NLRB, 170 F.2d 247 (1948), cert. denied, 336 U.S. 960 (1949), that employee retirement and pension plans are a mandatory subject of collective bargaining under Taft-Hartley.

s Pub. L. No. 85-836, 72 Stat. 997 (1958) (repealed 1976).

- H.R. Rep. No. 2283, supra note 38, at 10, reprinted in [1958] U.S. Code CoNG. \& AD. News at 4189 (emphasis added).

" Pub. L. No. 85-836, § 5(b), 72 Stat. 999 (1958) (repealed 1976).

2. Id. § 8, 72 Stat. 999 (1958) (repealed 1976).

is Id. § 8(b), 72 Stat. 1002 (1958) (repealed 1976).

" Id. \$ 6(b), 72 Stat. 999 (1958) (repealed 1976).

is Id. $\$ 7(\mathrm{~b}), 72$ Stat. 1000 (1958) (repealed 1976).

435 U.S. 497 (1978). 
Act, clearly indicate that Congress at the time recognized and preserved state authority to regulate pension plans." ${ }^{47}$

Underlying WPPDA was faith not only in state regulation, but in the ability of employees to negotiate adequate safeguards through collective bargaining and, with the help of laws requiring reporting and disclosure and prohibiting the most egregious forms of selfdealing and misappropriation, to police the resulting agreements for themselves. Theoretically, federal and state criminal statutes provided some protection against employee benefit plan abuses. The availability of criminal sanctions for theft, ${ }^{48}$ embezzlement, ${ }^{48}$ false statement, ${ }^{50}$ and bribery, ${ }^{51}$ was not, however, an effective deterrent. The difficulty in meeting the greater burden of proof necessary in a criminal action, combined with the procedural protections afforded criminal defendants, meant that few were indicted and fewer convicted. ${ }^{52}$ Moreover, criminal convictions have no remedial effect since they do not necessarily restore lost plan assets or alter imprudent practices and policies. Finally, many abuses, such as inadequate funding and vesting requirements, or improvidert administration, do not come under the ban of the criminal law at all.

Despite the panoply of state and federal laws appearing to regulate employee benefit plans, prior to 1974 participants and beneficiaries were in fact afforded few governmental guarantees that benefits would be available when promised. The basic misconception that undermined each of Congress's efforts was its premise that protection could be assured through minimal reporting and disclosure requirements and specific prohibitions of the most egregious forms of self-dealing and misappropriation, while leaving the imposition of substantive standards to state discretion. In recommending enactment of comprehensive federal regulation of employee benefit plans in 1972, the Senate Committee on Labor and Public Welfare acknowledged that WPPDA, the most extensive attempt to regulate benefit plans, had not achieved what its sponsors had hoped:

\footnotetext{
47 Id. at 505.

4 18 U.S.C. $\$ 664$ (1976).

"Id.

st Id. $\$ 1027$. This section now applies to the reporting and disclosure requirements of

s1 Id. § 1954. This section now applies to ERISA. See id.

32 According to one congressional study, only nine persons were indicted and six convicted for theft and embezzlement violations involving benefit plans in 1971; another sixteen persons were convicted under the bribery statute. S. REP. No. 634, 92d Cong., 2d Sess. 95 (1972). See United States v. Silverman, 430 F.2d 106 (2d Cir. 1970), cert. denied, 402 U.S. 953 (1971); United States v. Moore, 427 F.2d 38 (5th Cir.), cert. denied, 400 U.S. 965 (1970).
} ERISA. See id. 
Experience . . . has demonstrated the inadequacy of the Welfare and Pension Plans Disclosure Act in regulating the private pension system. It is weak in its limited disclosure requirements and wholly lacking in substantive fiduciary standards. Its chief procedural weakness can be found in its reliance upon the initiative of the individual employee to police the management of his plan..$^{53}$

The Committee's last criticism applied as well to many of the other state and federal laws regulating aspects of employee pension and welfare benefit plans. ${ }^{54}$ It was against this backdrop of ineffective federal and state regulation that Congress in 1974 enacted a comprehensive scheme for regulating employee benefit plans.

\section{B. The 1974 Act}

ERISA substituted mandatory federal standards for "the initiative of the individual employee." It did not do so across the board, however. Although all of the provisions of ERISA apply to pension plans, welfare plans need only comply with the reporting and disclosure provisions and observe the Act's fiduciary standards. ${ }^{55}$ In passing ERISA, Congress implemented its intent to protect participants in employee benefit plans by establishing standards of fiduciary conduct, requiring disclosure and reporting of financial information, providing minimum funding and vesting standards, requiring plan termination insurance, and providing appropriate remedies enforceable in the federal courts. These detailed regulatory and remedial provisions cut across the full spectrum of subject matter previously regulated by prior state and federal law.

1. Participation, Vesting, and Funding Standards. The enactment of ERISA strengthened, to varying degrees, the participation, vesting, and funding requirements for pension plans. ERISA left largely intact the tax qualification standards of section 401 (a) of the Internal Revenue Code ${ }^{56}$ and retained the Code's requirements of minimum eligibility and participation percentages. ${ }^{57}$ It did add to this minimum participation rule a minimum age and service requirement: generally every employee twenty-five years or older

sI S. REP. No. 1150, 92d Cong., 2d Sess. 5 (1972).

st See Pfenningstorf \& Kimball, supra note 7, at 793-96.

ss ERISA $\$ \S 201(1), 301(a)(1), 29$ U.S.C. $\S \S 1051(1), 1081(a)(1)(1976)$.

ss I.R.C. $\$ 401$ (a).

57 Id. $\$ 410(a)$. See Chadwick, ERISA's Minimum Participation and Vesting Standards, in 17 Textbook for Employee Beneft Plan Trustees, Administrators and Advisors: ProCEEdings of the 1975 ANNuAL Educational CoNFERENCE OF THE INTERNATIONAL Foundation of Employee BenefrT Plans 3 [hereinafter cited as 1975 TextBook]. 
must be eligible for plan participation after completing one year of service. ${ }^{58}$ Prior to ERISA, employers were not required to provide vested (nonforfeitable) rights to employees except as were required to qualify under the provisions of the Internal Revenue Code. ${ }^{39}$ With the enactment of ERISA, qualified plans must provide complete vesting of all accrued benefits derived from an employee's contributions, of normal retirement benefits when the employee reaches normal retirement age, and of all accrued benefits derived from the employer's contributions. ${ }^{60}$ With respect to the funding of pension plans, prior standards under the Internal Revenue Code required only that employers make contributions to defined-benefit pensions plans sufficient to pay normal pension costs based on actuarial calculations plus accrued interest on unfunded past-service liabilities. ERISA added to these rules a requirement that contributions be sufficient to amortize past-service liabilities ${ }^{61}$ and that experience losses be taken into account in establishing minimum funding. ${ }^{62}$

2. Termination Insurance. Title IV of ERISA established the Pension Benefit Guaranty Corporation"3 ("PBGC"), a government corporation within the Department of Labor, ${ }^{84}$ to ensure that participants and their beneficiaries receive at least partial benefits from tax-qualified defined-benefit plans that terminate with insufficient assets to meet plan liabilities. ${ }^{65}$ Upon termination of a covered plan,

ss I.R.C. $\$ 410(a)(1)(A)$.

so Id. $\$ 401(\mathrm{a})(7)$.

w Id. $\$ 411(\mathrm{a})$. Vesting must be under one of three alternative schemes: (1) full vesting after ten years of service, (2) full vesting after fifteen years on a prescribed graduated schedule, or (3) full vesting under the "rule of 45 ," which requires fifty percent vesting when the sum of the age of the employee and years of service equal 45, plus ten percent for each of the next five years. Id. See Chadwick, supra note 57; Slaughter, ERISA: Administrative Implementation of Participation, Vesting and Benefit Accrual, in 1975 TExтв00K, supra note 57, at 24 .

"I.R.C. § 412(b)(2)(B). See generally 18 Textrook ror Employe Bengrtr Plan Thustees, Administrators and Advisors: Proceedings of the 1976 Annual Educational Conference of the International Foundation of Employee Benefit Plans 159-89 (1976) [hereinafter cited as 1976 TEXTBOoK].

'2 I.R.C. \& 412(b)(2)(B)(iv)-(v). See Brownlee, Dealing with ERISA's Funding Requirements, in 1975 TexтвоoK, supra note 57, at 53. Qualified plans are required to set up "funding standard accounts," I.R.C. \$ 412(b)(1), see Gayda, The Funding Standard Account: What It Means and How It Works, in 1976 TExTBooK, supra note 61, at 164, in order to determine at the end of each year whether the employer has an "accumulated funding deficiency." I.R.C. \$ $412(a)$.

w ERISA $\S 4002(a), 29$ U.S.C. $\S 1302(a)$ (1976).

" 31 U.S.C. $\$ 846$ (1976).

c5 ERISA $\S 4002(a)(2), 29$ U.S.C. $\S 1302(a)(2)$ (1976). Pension plans that are tax qualified under section $401(\mathrm{a})$ of the Code, or have fulfilled the requirements of section 401 (a) for the preceding five years are within the coverage of PBGC. ERISA $\S 4021$ (a), 29 U.S.C. $\S 1321$ (a) (1976). 
participants are insured for the actuarial equivalent of the lesser of the employee's highest average monthly wage over any five year period of participation or $\$ 750$ per month.$^{66}$ Employers whose plans terminate may be required to reimburse $\mathrm{PBGC}$ for benefit payments despite earlier payment of insurance premiums to PBGC. ${ }^{67}$

3. Reporting and Disclosure. Although ERISA repealed the WPPDA, ${ }^{68}$ the new Act again imposed substantial reporting requirements on administrators of both pension and welfare benefit plans. ${ }^{69}$ Plans must publish and file with the Secretary of Labor an annual report ${ }^{70}$ including a financial statement prepared by an independent certified public accountant, ${ }^{71}$ and plans subject to the new vesting rules must file an annual registration statement with the Secretary of the Treasury ${ }^{72}$ to inform the Internal Revenue Service of participants with deferred vested benefits who are no longer employed by the plan sponsor. ${ }^{73}$ In addition to notifying these government agencies, plan administrators must provide participants with summary plan descriptions and annual reports ${ }^{74}$ and must give plan participants with deferred vested benefits individual statements showing the amount, nature, and form of vested benefits upon termination of their employment. ${ }^{75}$

4. Fiduciary Standards. Prior to the enactment of ERISA, state laws governed the conduct of employee benefit plan fiduciaries. These laws generally required them to exercise such skill as a man of ordinary prudence would exercise in dealing with his own property. ${ }^{76}$ Section 404 of ERISA modified the common-law

a Id. $\S 4022(\mathrm{~b})(3), 29$ U.S.C. $\S 1322(\mathrm{~b})(3)$ (1976).

"7 Id. § 4062, 29 U.S.C. § 1362 (1976). Employers maintaining single employer pension plans may be liable for the lesser of the full current value of benefits guaranteed by the Act less the current value of plan assets or thirty percent of the employer's net worth. Id. $\S$ 4062(b), 29 U.S.C. $\S 1362$ (b) (1976).

cs Id. $\S 111(\mathrm{a})(1), 29$ U.S.C. $\$ 1031(\mathrm{a})(1)(1976)$.

" Moore \& Berger, Reporting and Disclosure under ERISA, 45 J. KaN. B. Ass'N 103 (1976); Schwedt, Reporting and Disclosure: The DOL Component, in 1976 Texтвоoк, supra note 61, at 74; Stevens, Reporting and Recordkeeping as a Fiduciary Duty, in id. at 115. See generally id. at 115-55.

7 ERISA $\S \S 103(a)(1)(A), 104(a), 29$ U.S.C. $\S \S 1023(a)(1)(A), 1024(a)(1976)$.

${ }^{71} I d . \S \S 103(\mathrm{a})(1)(\mathrm{B})(\mathrm{i}), 103(\mathrm{a})(3)(\mathrm{A}), 29$ U.S.C. $\S \S 1023(\mathrm{a})(1)(\mathrm{B})(\mathrm{i}), 1023(\mathrm{a})(3)(\mathrm{A})$ (1976).

72 I.R.C. $\S 6057(\mathrm{a})(1)$.

73 See 7 Stand. Fed. Tax ReP. (CCH) If $5099 \mathrm{KK}$ (1978). The statement must provide the name of the plan, the name and address of the plan administrator, the name and taxpayer-identifying number of participants leaving the service of the employer and entitled to vested deferred benefits, and the nature, amount and form of the benefit. I.R.C. $\$$ 6057(a) (2).

74 ERISA $\$ \S 102,104(b), 29$ U.S.C. $\$ \S 1022,1024(b)(1976)$.

75 Id. § 105(c), 29 U.S.C. § 1025(c) (1976); I.R.C. \$ 6057(e).

" See Hutchinson, The Federal Prudent Man Rule Inder ERISA, 22 VuL. L. REv. 15, 26 (1976); Landau, Merholtz \& Perkins, Protecting a Potential Pensioner's Pension-An 
prudent-man rule somewhat to require fiduciaries of pension and welfare benefit plans to administer plans "with the care, skill, prudence, and diligence under the circumstances then prevailing that a prudent man acting in a like capacity and familiar with such matters would use in the conduct of an enterprise of a like character and with like aims." "Moreover, the Act requires fiduciaries to administer plans "solely in the interest of participants and beneficiaries and ... for the exclusive purpose of . . . providing benefits to participants and their beneficiaries; and . . . defraying reasonable expenses of administering the plan."78 In aid of this standard of conduct, ERISA requires that employee benefit plans be administered in trust form ${ }^{79}$ pursuant to a written document providing for one or more named fiduciaries. ${ }^{80}$ The Act also requires fiduciaries of a plan to adhere to plan documents and to diversify the investments of the plan to minimize the risk of large losses, ${ }^{81}$ imposes liability for the breach of these standards as well as for certain breaches by cofiduciaries, ${ }^{82}$ and proscribes fiduciaries from causing the plan to engage in "prohibited transactions" with a party in interest. ${ }^{83}$

5. Enforcement. To implement its substantive provisions, ERISA contains specific administrative, civil and criminal enforce-

Overview of Present and Proposed Law on Trustees' Fiduciary Obligations and Vesting, 40 BrookLyn L. REv. 521, 529-34 (1974); Note, Fiduciary Standards and the Prudent Man Rule Under the Employee Retirement Income Security Act of 1974, 88 HAnv. L. Rkv. 960 (1975).

$\pi$ ERISA $\$ 404(\mathrm{a})(1)(B), 29$ U.S.C. \$ 1104(a)(1)(B) (1976). See generally 1976 TExTB0oK, supra note 61, at 3-58; Landau, Merholtz \& Perkins, supra note 76, at 562-78; Gertner, Fiduciary Liability Under ERISA: A Review and a Preview, in 19 TextBook ror EMpLoyke Bengrit Plan Trustees, Administrators and Advisors: Procegdings of the 1977 annual Educational Conference of the International Foundation of Employee Bengft Plans 37, $39-40$ (1977) [hereinafter cited as 1977 Texтво0к]; Silverman, ERISA's Prudent Man, id. at 44 .

78 ERISA $\S 404(a)(1), 29$ U.S.C. $\S 1104(a)(1)$ (1976).

$\pi$ Id. $\S 403(\mathrm{a}), 29$ U.S.C. $\S 1103(\mathrm{a})$ (1976).

s Id. $\S 402(\mathrm{a})(1), 29$ U.S.C. $\$ 1102(\mathrm{a})(1)$ (1976). See Engroff, Understanding Plan and Trust Documents, in 1977 TExTBook, supra note 77, at 83. ERISA § 3(21)(A), 29 U.S.C. $\S$ $1002(21)(A)(1976)$, designates as a "fiduciary" to a plan each person who exercises discretionary authority or control respecting plan management, administration, or disposition of assets, or who renders investment advice for remuneration. The Department of Labor, with the IRS's concurrence, amplified this definition of "fiduciary" in an interpretive bulletin. 40 Fed. Reg. 47,491 (1975).

$"$ ERISA $\S 404(\mathrm{a})(1)(\mathrm{D}), 29$ U.S.C. $\$ 1104(\mathrm{a})(1)(\mathrm{D})$ (1976).

Id. $\$ 405,29$ U.S.C. $\$ 1105$ (1976).

\& Id. 406(a)(1), 29 U.S.C. $\$ 1106(a)(1)$ (1976). The Secretary of Labor may grant exemptions from prohibited transactions under procedures established pursuant to authority granted by Congress in ERISA $\$ 408,29$ U.S.C. $\$ 1108$ (1976). 40 Fed. Reg. 18,471 (1975); Rev. Proc. 75-26, 1975-1 C.B. 722. See also Chadwick, Prohibited Transactions and Office Space Leases: The Final Regulations and Exemptions, in 1977 TExтвоoк, supra note 77, at 61; Reagan, Prohibited Transactions Under ERISA, in 1975 Tвхтвоок, supra note 57, at 414; Retzack, In Search of an Exemption: One Union's Experience, in 1976 Texтв00K, supra note 61 , at 50-52. 
ment provisions. ${ }^{84}$ Responsibility for enforcing the civil remedial provisions of the Act lies with the Departments of Labor and the Treasury, ${ }^{85}$ criminal actions are initiated by the Secretary of Labor and prosecuted by the Justice Department. ${ }^{86}$ The Secretary of Labor may bring civil actions to remedy breaches of fiduciary duty, to seek equitable relief for violations of the Act, and to obtain damages for violations of the participation, vesting, and funding requirements of ERISA. ${ }^{87}$ In addition, any participant, beneficiary, or fiduciary may institute a civil action to compel disclosure of information required by the Act, ${ }^{88}$ to enjoin a violation of the plan or the Act ${ }^{89}$ or to seek relief for the plan administrator's failure to comply with the Act's reporting requirements. ${ }^{30}$ To enforce these civil remedies, ERISA establishes federal jurisdiction ${ }^{91}$ and provides for suits and enforcement of judgments against the plans as entities. ${ }^{92}$

\section{ERISA and the Problem of Preemption of State Law}

In enacting ERISA in 1974, Congress provided the first comprehensive federal regulation of private employee benefit plans. Since state law had previously regulated many aspects of such plans, ERISA involved not only the creation of new law but the displacement of a large body of existing state law. The extent of that dis-

ERISA §§ 501-514, 29 U.S.C. $\$ \S 1131-114 \dot{4}$ (1976). The White House Reorganization Plan No. 4, transmitted to Congress on August 10, 1978, and to be effective on or before April 30,1979 , has reallocated responsibilities between the Secretaries of Labor and the Treasury. 43 Fed. Reg. 47,713 (1978). Senators Williams and Javits would go farther in their proposed ERISA Improvements Act of 1979, and consolidate administration of ERISA in a new government agency. S. 209, 96th Cong., 1st Sess., \$§ 401-404 (1979). See 125 Cong. Rec. 570, 57172 (1979) (Sen. Javits's statement on the Senate Floor); text and notes at notes 324-328 infra.

ss See ERISA tit. III (codified at 29 U.S.C. $\$ \$ 1201-1242$ (1976), and in scattered sections of 26 U.S.C.).

s Id. § 506, 29 U.S.C. § 1136 (1976).

s Id. §502(a)(2), 29 U.S.C. $\$ 1132(a)(2)$ (1976). See Hutchinson, ERISA's Regulations and Fiduciary Responsibility: Keeping the Purpose in Mind, in 1975 Texтвоок, supra note 57 , at 354 .

s ERISA $\S \S 502(a)(1), 502(c), 29$ U.S.C. $\S \S 1132(a)(1), 1132(c)(1976)$.

Id. § 502(a)(3), 29 U.S.C. $\S 1132(\mathrm{a})(3)(1976)$.

* Id. § 502(a)(4), 29 U.S.C. \& 1132(a)(4) (1976).

"Id. § 502(e), 29 U.S.C. § 1132(e) (1976).

"2 Id. \$§ 502(d)(1), 502(2), 29 U.S.C. § 1132(d)(1), 1132(2) (1976). Section 502(d)(2) provides that money judgments "under this title" are enforceable only against the plan and not against the plan fiduciaries, unless there is an independent ground for individual liability. Plan trustees may, however, be individually liable under state common law for the contractual obligations of a plan.

ERISA also permits the court to award attorneys' fees in a suit by a participant, beneficiary, or fiduciary. Id. $\S 502(\mathrm{~g}), 29$ U.S.C. $\S 1132(\mathrm{~g})$ (1976). See Hutchinson \& Pagash, Awarding Attorneys Fees Under ERISA, 1 CoRP. L. Rev. 195 (1978); Hutchinson, Attorney's Fees Under ERISA: When, and Against Whom?, Nat'l L.J., Feb. 5, 1979, at 25. 
placement, the scope of federal "preemption" of state law in the field of private employee benefit plans, is the focus of the remainder of this article.

\section{A. The Preemption Doctrine}

Under the supremacy clause, congressional exercise of a granted power may supersede state regulation in the same area. ${ }^{93}$ This means, at the very least, that state law is unenforceable when it conflicts in its terms with valid federal law. ${ }^{94}$ Federal law need not impose substantive regulation to be preemptive, however. Congress may determine that a field under its regulatory control should be free of all regulation, state or federal, and legislate accordingly..$^{95}$

When there is no direct conflict between state and federal law, two questions arise: To what extent does federal activity in an area preclude the states from imposing nonconflicting regulations in the same area, and how broadly is the area "occupied by Congress" to be defined? In principle, the answers to both questions normally turn on congressional intent. The mere existence of federal activity will not necessarily eliminate all state governmental functions in the same area. Indeed, the opposite is the normal presumption: "Federal law is generally interstitial in nature. . . . Congress acts ... against the background of the total corpus juris of the states in much the way that a state legislature acts against the background of the common law, assumed to govern unless changed by legislation." ${ }^{\prime 96}$ Nevertheless, Congress need not express preemptive intent explicitly for courts to find that a federal statute preempts state law. A state regulation is preempted when it conflicts with a proper

is U.S. Const. art. VI, cl. 2. See G. Gunther, Cases and Matrrulas on Constitutional Law 127-34 (9th ed. 1975); L. Tribe, American Constitutional Law $\$ \S 6-24$ to -28 , at 376-94 (1978).

" "Congressional enactments that do not exclude all state legislation in the same field nevertheless override state laws with which they conflict." Jones v. Rath Packing Co., 430 U.S. 519, 525-26 (1977) (citations omitted).

is One commentator has characterized the preemption issue as follows: "Preemption problems arise whenever a state law is asserted to be unenforceable because it is contrary to a federal law, as when the state commands conduct which the federal law forbids, or when the federal government forbids state regulation of a field of activity subject to federal superintendence." Hirsch, Toward a New View of Federal Preemption, 1972 U. ILL. L.F. 515, 516.

" P. Bator, P. Mishikin, D. Shapiro, \& H. Wechsler, Hart \& Wechsler's The Federal Courts AND THE FEDERal SySTEM 470-71 (2d ed. 1973). There is also a minority view of the doctrinal basis of the preemption which holds that preemption only occurs when the states are unable to regulate the subject matter that is the source of concurrent state-federal jurisdiction. See Freeman, Dynamic Federalism and the Concept of Preemption, 21 De Paul L. REv. 630 (1972). The cases generally have not treated subject matter as an independent ground for preemption, but only as one factor in determining congressional intent. See Note, supra note 4 , at 625 . 
exercise of federal power or interferes with a federal system of regulation. ${ }^{97}$ Nor is a direct collision between state and federal law necessary, although courts are to infer Congress's preemptive intent from the structure of a statute or its legislative history only where the intent is "unmistakeable." Structure and legislative history are not unambiguous guides to statutory interpretation, but even when Congress does make it explicit that state law is preempted, courts still may have to examine the statute's structure and history to determine the precise boundaries of the preempted field. Under these circumstances, it is not surprising that decisions on preemption have an ad hoc quality, ${ }^{99}$ even though the Supreme Court has tried to explain its approach to preemption in a principled way. ${ }^{100}$

There are, however, underlying factors that help to explain the trend of decisions. Where state law is preempted, those matters not regulated by federal law in the preempted field may go completely unregulated. Although in the past courts often interpreted federal preemption broadly, more recently, with the decline in laissez-faire attitudes and the emergence of more general acceptance of government regulation, courts have tended towards an increased tolerance of state legislation that supplements federal action. ${ }^{101}$ In addition,

1 See Hart, The Relations Between Federal and State Law, 54 CoLum. L. REv. 489, 51725 (1954).

is The Court summarized this doctrine in Florida Lime \& Avocado Growers, Inc. v. Paul, 373 U.S. 132 (1963):

The principle to be derived from our decisions is that federal regulation of a field of commerce should not be deemed preemptive of state regulatory power in the absence of persuasive reasons-either that the nature of the regulated subject matter permits no other conclusion, or that the Congress has unmistakably so ordained.

Id. at 142.

" Note, supra note 4, at 625 . One commentator observed that "cases involving preemption of state law by federal statutes have often produced considerable confusion and criticism." Note, A Framework for Preemption Analysis, 88 YALE L.J. 363, 363 (1978) (footnotes omitted).

Another commentator attempted to synthesize the various considerations used by the Supreme Court in determining whether a state law has been preempted by federal legislation. These factors include:

whether the statute expressly bars state regulation of a subject; whether the scheme of federal regulation is so pervasive that it leaves no room for state action; whether the statute touches a field in which the federal interest is so dominant that the federal law must preclude enforcement of state law; whether the object sought to be obtained by the federal law and the character of the obligations imposed by it reveal the same purpose; and finally, whether the federal law governs a field where the need for national uniformity is so great that divergent state laws cannot be tolerated.

Brummond, Federal Preemption of State Insurance Regulation Under ERISA, 62 Iowa L. REv. 57, 95 (1976).

100 See, e.g., Jones v. Rath Packing Co., 430 U.S. 519, 525-26 (1977).

111 See, e.g., Florida Lime \& Avocado Growers, Inc. v. Paul, 373 U.S. 132 (1963); Parker v. Brown, 317 U.S. 341 (1943); L. TriaE, supra note $93, \S 6-24$, at 379 . The trend toward a 
there is discernible in some decisions a reluctance to expand the scope of national law to a point of undermining the authority of state government.

Two recent cases illustrate this trend most strikingly. In National League of Cities $v$. Usery, ${ }^{102}$ the Court struck down the 1974 amendments ${ }^{103}$ to the Fair Labor Standards Act ${ }^{104}$ that extended its substantive provisions to employees of the government of a state or one of its political subdivisions. ${ }^{105}$ The Court asserted that such extension of federal standards would "interfere with traditional aspects of state sovereignty," 106 observing that if Congress could preempt the states' authority to make fundamental employment decisions "there would be little left of the States' "separate and independent existence." " 107 Even where congressional authority is unquestioned, the Court has been loath to find preemptive intent in fields in which states have traditionally played an important role and have continuing responsibilities. In New York State Department of Social Services $v$. Dublino, ${ }^{108}$ the Court held that work requirements imposed by New York as a condition for receipt of federal welfare funds were not preempted by a federal program designed to achieve the very same ends. Justice Powell, writing an opinion joined by six other members of the Court, stressed that the Court should hesitate to invalidate compatible state regulations absent the express intent of Congress to exercise its article VI power. He concluded that holding the federal program to be the sole method of imposing work incentives "could impair the capacity of the state government to deal effectively with the critical problem of mounting welfare costs and the increasing financial dependency of many of its citizens," and he stressed the beneficence of a "scheme of cooperative federalism" to achieve the desired end. ${ }^{109}$

In cases such as Dublino, the Court appears to go beyond a mere inquiry into congressional intent or into whether the state law interferes with the federal regulatory scheme. Rather, absent explicit preemption by Congress or clear incompatibility of state and

moderate approach to the preemption doctrine may be a product of the present Court's generally restrained view of federal power. See Catz \& Lenard, The Demise of the Implied Federal Preemption Doctrine, 4 Hastings Const. L.Q. 295, 307-09 (1977).

102426 U.S. 833 (1976).

10 Fair Labor Standards Amendments of 1974, Pub. L. No. 93-259, 88 Stat. 55 (codified in scattered sections of 29 U.S.C.).

144 29 U.S.C. $\$ \S 201-219(1976)$.

in Id. $\$ \S 203(\mathrm{~d}), 203(\mathrm{x})(1976)$.

ies 426 U.S. at 849.

107 Id. at 851.

100413 U.S. 405 (1973).

in Id. at 413. 
federal laws, the Court has apparently been willing to risk a certain amount of interference with a federal system of regulation if the state interest is sufficiently strong, so long as the federal scheme is not completely disrupted. ${ }^{110}$

In 1973, in Goldstein v. California, ${ }^{111}$ the Court held that a state's right to prohibit the unauthorized reproduction of phonograph records was not preempted by the mere existence of a federal copyright statute that had long been interpreted as not regulating such reproduction. Similarly, in Kewanee Oil Co. v. Bicron Corp., ${ }^{112}$ the Court held that a state trade-secret law could protect the secrecy of inventions not covered by federal patent law. In both cases, the Court rejected the argument that the freedom to copy published material or to use inventions not protected by federal law was itself part of the federal regulatory scheme. Nor was the Court swayed by the possibility that inconsistent state regulations would create some interference with the exercise of federal power. In Kewanee, for example, the Court asked whether state protection would "cause a substantial risk that holders of patentable inventions would not seek patents, but rather would rely on the state protection."113 Finding no risk of such major disruption of the federal scheme, the Court upheld the state regulation.

The approach taken by the Court in these cases alters, subtly but significantly, the literal and traditional reading of the supremacy clause. The proper judicial inquiry is whether Congress intended to preempt state law pursuant to a delegated power. This should be accomplished through statutory construction aided by legislative history, not by a balancing of competing federal and state policy objectives. It is from this point of view that the following discussion examines federal preemption under ERISA.

\section{B. ERISA's Preemption of State Law}

Both the statutory language of ERISA and its legislative history make clear that Congress intended to occupy comprehensively the field of employee benefit plan regulation. ${ }^{114}$ Section 514(a) of ERISA expressly states that, except for the provisions of section 514(b), the

110 Note, supra note 4 , at 649-53.

111412 U.S. 546 (1973).

112416 U.S. 470 (1974).

its Id. at 489.

II See generally Shepard, ERISA in the Context of Federal Pre-emption: The Legislative Background, in 1976 TExTBook, supra note 61, at 452; Blomquist, Rebutting the NAIC Position Against Pre-emption of State Laws by ERISA, in id. at 457; Pantos, Preemption Litigation Under ERISA, 3 EMPLOYEE REL. L.J. 336 (1978); Pfenningstorf \& Kimball, supra note 7, at 800-09. 
provisions of titles I and IV "shall supersede any and all State laws insofar as they may now or hereafter relate to any employee benefit plan" within the jurisdiction of section 4(a) of ERISA. ${ }^{15}$ This broad preemptive language is tempered only somewhat by several limiting exceptions. Section 514(b)(1) provides that the broad preemptive effect of section 514(a) does not apply to causes of action arising before January 1,$1975 ;^{116}$ section 514 (d) provides a savings clause for other federal laws. ${ }^{117}$ Most significant of the exceptions to section $514(\mathrm{a})$ is section $514(\mathrm{~b})(2)(\mathrm{A})$, which provides a savings clause for state regulation of insurance, banking or securities. ${ }^{118}$ To prevent this clause from evolving into a large loophole through the characterization of benefit plans as insurance, section $514(\mathrm{~b})(2)(\mathrm{B})$ expressly prohibits such characterization. ${ }^{19}$ Finally, section $514(\mathrm{~b})(4)$ exempts from the broad preemptive scope of section 514(a) "any generally applicable criminal law of a State."120

The conference committee that adopted the sweeping language of section 514(a) made clear in its report that it intended the preemptive scope of the section to be broad:

[T] he provisions of Title I are to supersede all State laws that relate to any employee benefit plan that is established by an employer engaged in or affecting interstate commerce or by an employee organization that represents employees engaged in or affecting interstate commerce...

The preemption provisions of Title I are not to exempt any person from any State law that regulates insurance, banking, or securities. However, the substitute [language] generally provides that an employee benefit plan is not to be considered as an insurance company, bank, trust company or investment company (and is not to be considered as engaged in the business of insurance or banking) for purposes of any State law that regulates insurance companies, insurance contracts, banks, trust companies, or investment companies. ${ }^{121}$

i"s ERISA § 514(a), 29 U.S.C. § 1144(a) (1976).

11 29 U.S.C. $\S 1144(b)$ (1) (1976). See Malone v. White Motor Corp., 435 U.S. 497 (1978);

Azzaro v. Harnett, 414 F. Supp. 473 (S.D.N.Y. 1976).

11729 U.S.C. \& 1144(d) (1976).

118 Id. $\$ 1144(\mathrm{~b})(2)(\mathrm{A})$.

i' Id. \$ $1144(\mathrm{~b})(2)(\mathrm{B})$.

i2a Id. \& 1144(b)(4).

121 S. REP. No. 1090, 93d Cong., 2d Sess. 383 (1974).

The Conference Committee's intent to include a broad preemption provision is further evidenced by its consideration and rejection of the portion of the Administration's recommendations to the conferees concerning section 514. The Administration summarized the substi- 
The report stated that the statute made an exception only for plans "established primarily to provide death benefits," which were to continue to be regulated under state insurance law and other applicable state law. Moreover, during the final debates on ERISA, its broad preemptive scope was emphasized in both the Senate and the House. The Chairman of the Senate Committee on Labor and Public Welfare, Senator Harrison Williams, Jr., stressed that preemption was necessary to eliminate "the threat of conflicting or inconsistent State and local regulation of employee benefit plans." 122 This, he explained, meant that "all actions of State or local governments" having the effect of law were to be preempted.123

Preemption had strong bipartisan support. The senior Republican member of the Senate Committee on Labor and Public Welfare, Senator Jacob Javits, said:

In view of Federal preemption, state laws compelling disclosure from private welfare or pension plans, imposing fiduciary requirements on such plans, imposing criminal penalties on failure to contribute to plans-unless a criminal statute of general application-establishing State termination insurance programs, et cetera, will be superseded. It is also intended that a body of Federal substantive law will be developed by the courts to deal with issues involving rights and obligations under private welfare and pension plans. ${ }^{124}$

Senator Javits explained that the conference had opted for such broad preemption to avoid the dangers feared from earlier Senate and House versions of the bill, which had more narrowly defined the perimeters of preemption only "in relation to the areas regulated by the bill":

Such a formulation raised the possibility of endless litigation

tute language as follows:

The Administration has prepared a preemption clause ... which makes explicit the areas of state law to be preempted. They are as follows: participation, vesting, funding, disclosure and fiduciary standards, portability, termination insurance, enforcement and additional plan requirements (as set out in House bill Section 1021 which includes joint and survivor annuity requirements and provisions against alienation of benefits). The preemption section should make clear that a state could not set minimum standards for retirement plans in the areas listed above; however, it could regulate the tax aspects of retirement plans.

Administration Recommendations to the House and Senate Conferees of H.R. 2 to Provide for Pension reform, reprinted in 3 Legislative History of ERISA, supra note 18, at 5145.

122120 CoNG. REc. 29,933 (1974),

120 Id.

121 Id. at $29,942$. 
over the validity of State action that might impinge on Federal regulation, as well as opening the door to multiple and potentially conflicting State laws hastily contrived to deal with some particular aspect of private welfare or pension benefit plans not clearly connected to the Federal regulatory scheme . . . .

[C]omprehensive and pervasive Federal interest and the interests of uniformity with respect to interstate plans required-but for certain exceptions-the displacement of State action in the field of private employee benefit programs. ${ }^{125}$

Senator Javits also made it clear that the conferees were aware that such broad preemption might create regulatory lacunae or lead to other, unforeseen problems. They chose, however, not to limit the scope of preemption, but to entrust to a watchdog body the task of recommending new legislation as needed. The conferees, he said, recognized the broad dimensions of ERISA's preemption provisions and determined that the Congressional Pension Task Force should evaluate their effects. If the Task Force found that ERISA was precluding essential state or federal legislation, Congress could make "appropriate modifications" in the statute. ${ }^{128}$

Congressman John Dent, the Chairman of the Subcommittee on Labor of the House Labor and Education Committee, explained and defended preemption in similar terms on the floor of the House. "The conferees, with the narrow exceptions specifically enumerated, applied this principle [preemption] in its broadest sense to foreclose any non-Federal regulation of employee benefit plans." 127 They did this to eliminate "the threat of conflicting and inconsistent State and local regulation." 128 Congressman Dent stressed that reserving "to Federal authority the sole power to regulate the field of employee benefit plans" was "to many the crowning achievement of this legislation." 129

That ERISA's structure, language, and legislative history support a broad interpretation of the scope of federal preemption of state law in this field has not been seriously questioned by many. Federal district courts generally have concluded that "federal preemption in the area of pensions and other employee benefit programs is virtually total." ${ }^{130}$ In a particularly thoughtful opinion,

125 Id.

126 Id. See text and notes at notes 324-339 infra.

127120 CoNG. RBC. at 29,197 (1974).

128 Id.

12 Id.

130 Bell v. Employee Security Benefit Ass'n, 437 F. Supp. 382, 387 (D. Kan. 1977). See also Marshall v. Chase Manhattan Bank, 558 F.2d 680, 683 (2d Cir. 1977); Hewlett-Packard 
Judge Renfrew of the District Court of the Northern District for California, after examining the legislative history of section 514, concluded that "Congress carefully considered the question of preemption, including the feasibility of enacting a more limited preemption provision, and . . . ultimately enacted section 514(a) with the express purpose of summarily preempting state regulation of ERISA-covered employee benefit plans."131

Opinion letters issued by the Department of Labor have also interpreted the legislative history of section 514 as indicating a congressional intent to occupy the field. One such letter concluded by referring to the remarks of Senator Williams on the Senate floor:

The major reasons for broad preemption disclosed in these remarks are (1) the need to prevent conflicting regulation over interstate plans, (2) the desire to avoid the litigation that would result from piecemeal preemption, (3) the emergence of a pervasive Federal interest in employee benefit plans, and (4) the existence of a comprehensive federal program for further study .......132

Nevertheless, in spite of such general agreement on the preemptive scope of section 514, courts have begun to carve out exceptions to it, and both the administrative agencies and congressional committees have occasionally supported or acquiesced in these decisions. There is a natural tendency to restrict the scope of preemption where it appears to produce an inequitable result in a particular case. Equally important, since ERISA regulates only reporting and fiduciary standards in the case of welfare benefit plans, and since

Co. v. Barnes, 425 F. Supp. 1294, 1298 (N.D. Cal. 1977); Pfenningstorf \& Kimball, supra note 7 , at 801 .

131 Hewlett-Packard Co. v. Barnes, 425 F. Supp. 1294, 1300 (N.D. Cal. 1977). The testimony heard by Congress regarding federal preemption cited in Hewlett-Packard included: Proposed Welfare and Pension Plan Protection Act: Hearings on H.R. 5741 before the Subcomm. on Labor of the House Comm. on Education and Labor, 90th Cong., 2d Sess. 186 (1968) (statement of Andrew J. Biemiller, Director, Department of Legislation, AFL-CIO); Proposed Revisions of the Welfare and Pension Plans Disclosure Act: Hearings on H.R. 2 \& H.R. 462 before the Subcomm. on Labor of the House Comm. on Education and Labor, 93d Cong., 1st Sess., pt. 1, at 315 (1973) (statement of Preston C. Basset on behalf of Towers, Perrin, Forster \& Crosby, Inc.); id., pt. 2, at 651 (statement of Lauren Upson, Member, California Banker's Association Committee on Employee Benefit Trusts); id., pt. 1, at 554-55 (statement of Robert D. Haase, Commissioner of Insurance, State of Wisconsin); id., pt. 2, at 188-95 (statement of Stanley C. Du Rose, Jr., Commissioner of Insurance of the State of Wisconsin). See also text and notes at notes 292-320 infra.

132 Department of Labor Opinion Letter 75-130 (July 18, 1975). See also Department of Labor Opinion Letter 76-90 (July 14, 1976); Department of Labor Opinion Letter 76-84 (June 22, 1976); Department of Labor Opinion Letter 75-143 (October 30, 1975); Department of Labor Opinion Letter 75-135 (October 15, 1975). 
employee benefit plans intersect with many areas traditionally left to state governance, there is tension between the broad preemption intended by Congress when it enacted ERISA and the recent tendency of the courts to restrict the scope of federal preemption where it threatens to create a regulatory vacuum or where it interferes with state regulation of a field traditionally left to state control.

\section{What Is a Plan?}

In enacting ERISA, Congress did not intend to preempt state regulation of every conceivable arrangement promising future benefits to employees. Regardless of the ultimate scope of section 514, state law affecting an employee benefit program is not preempted if the program is not a "plan" within the meaning of section 3 of ERISA. ${ }^{133}$ Difficult line-drawing questions have arisen with regard to benefit packages marketed by insurance companies or other entrepreneurs, in whose management neither employers nor employees participate to any significant extent. A broad reading of section 3 would cover such a plan if it is "established" or "maintained" by an employer, employee organization, or both, and would use the definition of "employer" in section 3(5), which includes "any person acting directly as an employer, or indirectly in the interest of an

135 ERISA defines employee benefit plans as follows:

(1) The terms "employee welfare benefit plan" and "welfare plan" mean any plan, fund, or program which was heretofore or is hereafter established or maintained by an employer or by an employee organization, or by both, to the extent that such plan, fund, or program was established or is maintained for the purpose of providing for its participants or their beneficiaries, through the purchase of insurance or otherwise, (A) medical, surgical, or hospital care or benefits, or benefits in the event of sickness, accident, disability, death, or unemployment, or vacation benefits, apprenticeship or other training programs, or daycare centers, scholarship funds, or prepaid legal services, or (B) any benefit described in section $186(C)$ of this title (other than pensions on retirement or death, and insurance to provide such pensions).

(2) The terms "employee pension benefit plan" and "pension plan" mean any plan, fund, or program which was heretofore or is hereafter established or maintained by an employer or by an employee organization, or by both, to the extent that by its express terms or as a result of surrounding circumstances such plan, fund, or program-

(A) provides retirement income to employees, or

(B) results in a deferral of income by employees for periods extending to the termination of covered employment or beyond,

regardless of the method of calculating the contributions made to the plan, the method of calculating the benefits under the plan or the method of distributing benefits from the plan.

(3) The term "employee benefit plan" or "plan" means an employee welfare benefit plan or an employee pension benefit plan or a plan which is both an employee welfare benefit plan and an employee pension benefit plan.

ERISA § 3(1)-(3), 29 U.S.C. \& 1002(1)-(3) (1976).

ERISA section 4 specifies which of the plans within the definition of section 3 are within the coverage of title I of the Act. 29 U.S.C. $\$ 1003$ (1976). 
employer" as well as "a group or association of employers."134 Courts, however, have sometimes given section 3 a more restrictive interpretation, especially when upholding state regulation of multiple employer trusts.

\section{A. Multiple Employer Trusts}

Multiple employer trusts, which have experienced rapid growth since the enactment of ERISA, ${ }^{135}$ enable employers of small numbers of employees to pool their resources in order to provide welfare benefits similar to those offered by larger employers. ${ }^{136}$ Typically, these trusts are organized and managed by a third-party administrator who may be an agent for an insurance company or an independent organization. The plans may be self-funded, insured by independent carriers, or self-funded in part and insured in part. ${ }^{137}$

The central question is whether a multiple employer trust is a variety of insurance or an employee benefit plan under section 3 of ERISA. Regulation of insurance is a matter that has been committed to the states by Congress under the McCarran-Ferguson Act. ${ }^{138}$ In addition, insurance plans, if they are not "employee benefit plans," are excluded from the scope of preemption by the savings

1329 U.S.C. $\$ 1002(5)$ (1976).

13s According to testimony offered by the National Association of Insurance Commissioners (NAIC) before an ERISA oversight hearing held by the House Labor Subcommittee on Labor Standards, an estimated 600,000 persons are participants in self-funding multiple employer trusts ("METs") operated by at least 30 MET organizations. NAIC further estimated that these plans collect over $\$ 300$ million each year and that over $\$ 3$ million worth of pensions are currently receiving welfare benefits from uninsured funds.

NAIC charged that these contributions are often mismanaged or expended on administrative costs, including excessive commissions, leading to insolvency. According to NAIC, at least five uninsured METs became insolvent between January 1977 and June 1978. Oversight on ERISA, 1978: Hearings on Public Law 93-406 Before the Subcomm. on Labor Standards of the House Comm. on Educ. \& Labor, 95th Cong., 2d Sess. 658-59 (statement of National Association of Insurance Commissioners by Herbert W. Anderson, Chairman of NAIC ERISA Preemption Task Force) [hereinafter cited as NAIC Statement].

${ }^{136}$ Multiple employer trusts should not be confused with "multiemployer" trusts or plans that are established between a labor union and more than one employer pursuant to a collective bargaining agreement. ERISA $\S 3(37)$, 29 U.S.C. $\S 1002(37)$ (1976). See T.D. 7552, 43 Fed. Reg. 29,939-42 (1978) (IRS definition of multiemployer plan).

${ }_{137}$ Fletcher, Preemption and the Multiple Employer Trust (MET) Problem, in 1977 Texтвоoк, supra note 77, at 71, 73. See generally Tomar, ERISA: Boon or Bane for SelfFunded Welfare Plans, in 1975 TExTBook, supra note 57, at 374.

izs 15 U.S.C. $\$ \S 1011-1015$ (1976). Section 1011 provides:

Congress hereby declares that the continued regulation and taxation by the several States of the business of insurance is in the public interest, and that silence on the part of the Congress shall not be construed to impose any barrier to the regulation or taxation of such business by the several States.

Id. $\S 1011$. Section 1012(b) provides that no federal law shall be construed to preempt a state insurance law "unless such Act specifically relates to the business of insurance." 
clause of section 514(b)(2)(A). ${ }^{139}$ Even before the enactment of ERISA, there were substantial questions regarding the method and extent of state regulation of self-insured benefit plans. ${ }^{140}$ After ERISA took effect, administrators of some multiple employer trusts took the position that such trusts are immune from state regulation because they are employee benefit plans under exclusive federal jurisdiction. ${ }^{141}$ The consequence of this argument would be a potential regulatory vacuum since, if a multiple employer trust does qualify as a welfare benefit plan, the substantive provisions of ERISA would not impose any requirements on the plan other than reporting and observance of the fiduciary standards: the vesting and funding provisions of ERISA cover only pension plans. ${ }^{142}$

Neither a definitional approach nor an analysis from the perspective of the policy of employee protection can provide a clearcut and consistent answer to the question whether a multiple employer trust is a plan under section 3 of ERISA. Although many multiple employer trusts are insurance packages offered by insurance companies or organized through other means, and do not meet the definition of a plan under section 3 , there are multiple employer trusts that may meet the components of the statutory definition of an "employee benefit plan." In principle, this determination should turn on the plain meaning of the statute. ${ }^{143}$

Unfortunately, whether a multiple employer trust falls within

'3s Id. \$ 1144(b)(2)(A).

14 Doubt focused both on the character of the plans as insurance and on federal preemption under LMRA and WPPDA. See Metropolitan Police Retiring Ass'n v. Tobriner, 306 F.2d 775 (D.C. Cir. 1962); Jordan v. Group Health Ass'n, 107 F.2d 239 (D.C. Cir. 1939); West \& Co. v. Sykes, 257 Ark. 245, 515 S.W.2d 635 (1974); Goetz, Regulation of Uninsured Employee Welfare Plans Under State Insurance Laws, 1967 Wis. L. Rev. 319; Note, Insurance Regulation-Employee Benefit Plans, 28 ARK. L. REv. 515 (1975); Note, Self-Insured Employee Welfare Plans and the 501(c)(9) Trust: The Specter of State Regulation, 43 U. CiN. L. REv. 325 (1974).

i1 Under the argument advanced by the METs, ERISA is claimed to be a federal statute specifically relating to insurance and hence not within the McCarran Act. See Brummond, The Legal Status of Uninsured Noncollectively-Bargained Multiple Employer Welfare Trusts Under ERISA and State Insurance Laws, 28 SYRAcuse L. REv. 701, 719 (1977). This argument, however, still must deal with section $514(\mathrm{~b})(2)(\mathrm{A})$ of ERISA, 29 U.S.C. $\$ 1144(\mathrm{~b})(2)(\mathrm{A})$ (1976), which expressly provides that ERISA does not preempt state insurance law. See text and note at note 118 supra, and text and notes at notes 259-272 infra. The METs have countered this position" by contending that the "deemer" provision of ERISA section 514(b)(2)(B), 29 U.S.C. $\$ 1144$ (b)(2)(B) (1976), which forbids states to regulate an employee benefit plan by merely deeming it to be "insurance," precludes state regulation of METs as de facto insurance companies. But see Brummond, supra, at 723.

142 See text and note at note 55 supra.

113 The Supreme Court has held that "[i]n the absence of persuasive reasons to the contrary, we attribute to the words of a statute their ordinary meaning." Banks v. Chicago Grain Trimmers Ass'n, 390 U.S. 459, 465 (1968). 
the specific provisions of section 3 has little to do with whether preemption under ERISA seriously threatens employee interests. Paradoxically, preemption is least likely to do extensive damage in the case of programs fully insured with independent carriers, ${ }^{144}$ but these programs are often hard to distinguish from other insurance packages and are least likely to meet the definition of a plan under section $3 .{ }^{145}$ Problems may arise even with regard to these plans. For example, administrators of fully insured plans typically act in a dual capacity, as sales agents for the insurance company and as managers responsible for the trust's claims administration, ratemaking, benefit design, and general administration. ${ }^{146} \mathrm{~A}$ multiple employer trust that is fully insured, however, holds the policy of the carrier as its principal asset, and state regulation of the insurance company will offer protection in the area of underwriting practices and reserves. Therefore, preemption of such plans does not create a great risk of ultimate losses to participants as a group, although to leave vesting and benefit provisions unregulated may leave individuals without adequate protection in particular cases. ${ }^{147}$

Self-funded multiple employer trusts would not offer the same contingent protections if they were held to be ERISA-covered employee benefit plans. Benefit plans are rarely fully funded. Selffunded trusts lack the contingency reserves of insurance companies, and their legal liability is limited to actual trust assets, so that there is greater risk that such plans will be unable to meet their obligations. Preemption would exempt these plans from any indirect minimum funding requirements that the states might otherwise impose. Unfortunately, the growing reluctance of insurers to expand their involvement in this area following the failure of several multiple employer trusts has resulted in an increase in the number of such trusts electing to rely on self-funding. ${ }^{148}$

To define all multiple employer trusts as ERISA plans may

iu See Brummond, supra note 141, at 701-02; cf. Wadsworth v. Whaland, 562 F.2d 70 (1st Cir. 1977) (state insurance law imposed mandatory substantive provisions on plans), discussed at notes 262-266 infra.

145 See, e.g., Wayne Chem., Inc. v. Columus Agency Serv. Corp. 567 F.2d 692 (7th Cir. 1977), discussed at notes $163-169$ infra.

"' Bolnick, Multiple Employer Trusts, 78 Best's Rev. 20 (1977); A. Thaler, Some Thoughts of a Consulting Actuary on the Subject of Self-Insured M.E.T. Business 2-3 (Dec. 7,1976 ) (unpublished paper on file with The University of Chicago Law Review).

117 See note 145 supra.

Iss See Fletcher, supra note 137, at 73. In 1977 and the first half of 1978, at least five selfinsured METs became insolvent. 106 DAILY TAX REP. (BNA) G-9 (June 1, 1978). The reduced margin of actuarial error self-funded plans have in comparison with insured plans makes some provision for stop-loss insurance advisable for self-funded METs to help cushion unexpected loss experiences. 
extend the scope of preemption to insurance packages masquerading as employee benefit plans. It would also leave some employees without adequate protection, particularly those covered by unfunded and uninsured plans. To track the language of section 3 literally might, on the other hand, produce results that appear inconsistent, formalistic, and unrelated to the policy of employee protection. Finally, to exclude all multiple employer trusts from the scope of the definition of "employee benefit plan" is to react to a difficult public policy problem by adopting a simplistic interpretation that overlooks many of the component factors that determine whether something is a "plan" within the meaning of ERISA. For a court to ignore the plain language of ERISA because of the court's perception that employee protection calls for state regulation threatens the integrity of ERISA as a uniform, nationwide regulatory scheme; nor is it clear that multiple employer trusts are necessarily more in need of state regulation than other kinds of employee welfare benefit plans that are subjected only to federal reporting and fiduciary standards because they are more clearly covered by sections 3 and 514 of ERISA.

Nevertheless, congressional committees, the Department of Labor, and the courts have generally responded to the definitional and policy issues by holding that multiple employer trusts lie outside the scope of the definition of employee benefit plans for purposes of preemption under section 514. After expressing concern that "certain entrepreneurs" interested in profiting from administering the plans were marketing insurance products free of state regulation under the guise that they were in fact covered by ERISA, the House Committee on Education and Labor concluded that these plans were not among the "employee benefit plans" defined in section 3(3) of ERISA. ${ }^{149}$ The Committee stated that such programs were established not to bring them within the jurisdiction of ERISA, but for the purpose of marketing insurance to plan participants. These plans, the Committee said, were indistinguishable from other insurance policies sold to employee benefit plans. The Committee concluded, thus, that state regulation of such programs is not preempted, "even though such state action is barred with respect to the plans which purchase these products." 150

In a recent case involving the status of a multiple employer trust, the Department of Labor has also supported a restric-

to H.R. REP. No. 1785, 94th Cong., 2d Sess. 38, 48 (1977). See also David, Employee Benefit Trusts' Growth Alarms Officials; More Failures Feared, Bus. Ins. 1 (Feb. 21, 1977).

150 H.R. REP. No. 1785, supra note 149, at 48. 
tive-although not indefensible-definition of what constitutes an employee benefit plan under ERISA. In its amicus brief in Bell $v$. Employee Security Benefit Association ${ }^{151}$ the Department argued that the program was not an ERISA plan because the Employee Benefit Security Association ("ESBA") was not an employee organization. Since ESBA did not claim to be an employer, an employer association, or a labor union, the Department's brief focused on whether the plan was within ERISA because ESBA was either an employee representation committee or an employee beneficiary committee, and argued that it was neither. The Department contended that ESBA was not an employee representation committee because employee participation was almost nonexistent and ESBA had no contact with employers. ${ }^{152}$ It contended that ESBA was not an employee beneficiary association because its participants lacked any commonality of interest with respect to their employment relationships. ${ }^{153}$

The district court agreed that ESBA was insurance rather than an employee benefit plan and therefore subject to state regulation. ${ }^{154}$ The court made extensive inquiry into the distinctions between insurance and welfare plans, asserting that the substance, rather than the name of the plan, must control: "[J]ust as a state cannot regulate an employee benefit plan by calling it insurance, neither can defendants merchandise an insurance program, free of state regulation, by terming it an employee benefit plan." 155 The court appeared particularly impressed by the fact that ESBA was an entrepreneurial venture without bona fide employee participation and that coverage was marketed directly to participants by ESBA rather than through a preexisting organization. ${ }^{156}$ The court was also influenced, however, by its belief that such plans needed more regulation than ERISA provided, noting that the failure of other, similar

$15 t$ Memorandum of Secretary of Labor, Amicus Curiae, Bell v. Employee Benefit Ass'n, 437 F. Supp. 382 (D. Kan. 1977), reprinted in 150 PENs. REP. (BNA) R-1 (Aug. 15, 1977) [hereinafter cited as Amicus].

152 Id. at R-2.

15s Id. In asserting a requirement of commonality as part of the definition of an employee beneficiary committee, the Department relied on interpretations of identical language in WPPDA. See WPPDA $\S 3(\mathrm{a})(3), 29$ U.S.C. $\S 302(\mathrm{a})(3)$ (1970) (repealed 1976).

15437 F. Supp. 382 (D. Kan. 1977). The litigation in Bell was initiated by the State Commissioner of Insurance who sought to enjoin the plan from conducting business in Kansas until it complied with state insurance statutes and regulations. Id. at 384 .

155 Id. at 390.

156 Id. at 392-94. The court pointed out that employees participate in more traditional employee benefit plans through their membership in labor organizations. ESBA, on the other hand, provided only for an annual meeting in which the court termed employee participation to be a "fiction," since participants were required to sign a proxy on purchase of their policy appointing a plan official as their representative in the event of their nonattendance. 
enterprises demonstrated the need for regulation by the state. ${ }^{157}$ Finally, the court found support for its decision in the legislative history of ERISA ${ }^{158}$ and in the report of the House Oversight Task Force. 159

Although in Bell, the court did attempt to apply the components of the statutory definition of an employee benefit plan, other cases have paid less attention to the statutory language. In Hamberlin v. VIP Insurance Co., ${ }^{180}$ a federal district court in Arizona also found a multiple employer trust to be insurance subject to state regulation, rather than an immune ERISA plan. ${ }^{181}$ The VIP multiple employer trust originally had been fully insured, but it became self-funded at the initiative and under the direction of the trusts insurance brokers when its insurance company cancelled the trust's coverage. The court observed that the trust was continued in order for the brokers to continue receiving commissions and to maintain business relations with their customers, and that the brokers had designated the trust as an ERISA plan in order to avoid state insurance regulation. ${ }^{162}$ It is doubtful that the intent of the organizers of a plan should determine the ERISA status of the plan, yet here it apparently influenced the court's conclusion that the plan was in fact an entrepreneurial enterprise rather than an employee benefit plan.

A different approach to enhancing employee protection was adopted by another district court in Wayne Chemical Inc. v. Columbus Agency Service Corp. ${ }^{183}$ The employer-plaintiff had purchased a group medical insurance policy for some of its employees from the Columbus Agency Service Corporation ("CASCO"), which was in turn an agent for the National Multiple Employers Foundation ("NMEF") and the Association Life Insurance Company. The policy was formally transferred to NMEF on July $1,1975 .{ }^{164}$ When an employee of Wayne Chemical attempted to claim under the policy on behalf of his 18-year-old son who was paralyzed in an accident, he was informed that the benefits would terminate on his son's

157 Id. at 392.

15s Id. at 385-87. See text and notes at notes 93-132 supra.

iso Id. at 392. See note 149 supra.

16 434 F. Supp. 1196 (D. Ariz. 1977).

111 Id. at 1197,1200 . The State Insurance Director also instituted proceedings in state court to be appointed receiver of the defendant trust in order to protect beneficiaries whose claims were cut-off by the trustee's termination of the trust as financially unsound. Id. at 1197.

162 Id. at 1198.

is 426 F. Supp. 316 (N.D. Ind. 1977), aff'd on other grounds, 567 F.2d 692 (7th Cir. 1977).

IU Id. at 318 . 
twentieth birthday, a result prohibited under Indiana law. ${ }^{165}$ The district court held that the plan was within the jurisdiction of ERISA and that the provisions of Indiana law under which recovery would have been permitted were preempted. ${ }^{160}$ The court nevertheless held for the plaintiffs by adopting the applicable Indiana statute as federal common law. ${ }^{167}$

The Seventh Circuit affirmed the judgment, but on different grounds, holding that both the insolvent insurer and the agent selling the policy were subject to Indiana law and rejecting their claim that state regulation had been preempted by ERISA. The court held that the plan was not an employee benefit plan but, rather, insurance. ${ }^{168} \mathrm{NMEF}$, the court found, had been engaging in the insurance business in Indiana without the appropriate state certification, and thus both NMEF and its agent, CASCO, were held liable to the plaintiffs. After engaging in only a superficial analysis of the specific definition of "plan" under the Act, the court rested its decision on the rationale that Congress would have had no reason to oust state regulation of entrepreneurial insurance programs as a consequence of its intent to govern employee benefit plans. ${ }^{169}$

Permitting multiple employer trusts to operate in a regulatory vacuum is an unacceptable public policy. Even under the lower court's approach in Wayne Chemical, governance of multiple employer trusts would have been left to ad hoc determinations by federal courts, usually after insolvency of a plan and damage to participants. Under many self-funded plans, it is possible that beneficiaries of an insolvent trust will simply end up in line with other creditors for a drastically reduced share of the remaining assets. By leaving regulation of multiple employer trusts in the hands of the states, courts have reached a result that will enable state insurance regulatory bodies to provide prospectively for the protection of plan participants and beneficiaries. ${ }^{170}$

165 Id. at 319 .

16e Id. at 321.

167 Id. at 325. Cf. In re C.D. Moyer Co. Pension Trust, [1978] Pens. Plan Gume (CCH) If 22,934 (E.D. Pa. Oct. 28, 1978) (court promulgated general rule of federal common law under ERISA since statute did not specifically deal with the issue before the court). See generally Textile Workers Union v. Lincoln Mills, 353 U.S. 448, 456-57 (1957); Zdanok v. Glidden Co., 327 F.2d 944, 951 (2d Cir.), cert. denied, 377 U.S. 934 (1964).

is 567 F.2d 692, 699-700 (7th Cir. 1977).

i1' Id. at 699.

170 See also National Business Conference Employee Benefit Ass'n v. Howatt, [1978] Pens. Plan Gutde (CCH) If 22,778 (D. Or. Dec. 27, 1977) (multiple employer trust not an employee benefit plan under ERISA and hence subject to state insurance regulation). The superintendent of the New York State Insurance Department also has determined that six METs were not ERISA plans but providers of insurance and hence subject to state law. In 
Nevertheless, ERISA clearly preempts state authority over plans that meet the definition of section 3 , and if a multiple employer trust meets these terms, state law should be held preempted. If the results of this legal analysis seem undesirable, if state regulation of multiple employer trusts would be more effective than federal regulation under ERISA, ${ }^{171}$ the solution should be found in legislative amendment rather than in the characterization of all multiple employer trusts as outside the coverage of ERISA. This is not merely a formalistic argument; the scope of preemption should be defined not in terms of the perceived needs of particular plans for state regulation, but in terms of the more fundamental policy of ERISA to displace state regulation of employee benefit plans ${ }^{172}$ and to provide a single, comprehensive, uniform regulatory scheme for employee pension and welfare benefit plans.

\section{B. Legal Services Plans}

The question of what constitutes a "plan" under ERISA has arisen in other contexts, such as with regard to legal services plans. ${ }^{173}$ Legal services are a recent addition to employer-funded fringe benefits, following an amendment to the Taft-Hartley Act making such services a permissible benefit of funds subject to TaftHartley's jurisdiction. ${ }^{174}$ The growth of prepaid legal services plans may permit the delivery of legal services to a wider segment of the public, ${ }^{175}$ but complications are certain to arise in reconciling competing regulatory schemes.

Legal service benefit plans raise two sorts of practical considerations. As in the case of multiple employer trusts, preemption by ERISA would subject legal services plans only to reporting and fiduciary requirements, and these might not be sufficient to protect employee interests. In addition, regulation of the legal profession, like insurance, has traditionally been left to state governance, and

an opinion letter of June, 1977, and an April 17, 1978, addendum, the Superintendent ruled that the failure of the METs to conform to New York licensing and regulatory policies subjects insurance licensees of the state to the suspension or revocation of licenses and fines, and nonlicensees to prosecution for acting on behalf of the plans. 187 PENS. REP. (BNA) A-6 (May 5, 1978); 145 id. at A-9 (July 11, 1977).

i7 See, e.g., Brummond, supra note 141, at 739.

172 See Oversight on ERISA, supra note 135, 542-43 (summary of statement of the ERISA Industry Committee [ERIC]); id. at 359-61 (statement of Ray Marshall, Secretary of Labor).

is See generally Pfenningstorf \& Kimball, supra note 7.

17 Act of Aug. 15, 1973, Pub. L. No. 93-95, 87 Stat. 314.

${ }^{173}$ See generally, Bartosic \& Bernstein, Group Legal Services as a Fringe Benefit: Lawyers for Forgotten Clients Through Collective Bargaining, 59 VA. L. Rzv. 410 (1973). 
such regulation might clash with the regulation, or the freedom from regulation, that legal services plans might enjoy under the ERISA regime. Congress did, however, speak directly to the issue of legal services plans. Section 3(1) of ERISA defines "employee welfare benefit plan" as including "prepaid legal services."176 It is therefore apparent that Congress intended ERISA, and not state law, to regulate benefit plans providing prepaid legal services as a fringe benefit. ${ }^{177}$ Nonetheless, as with multiple employer trusts, prepaid legal services plans of a primarily entrepreneurial character have been construed not to be ERISA-covered "plans." 178

In Suffolk County Bar Association v. Law Research Service, Inc. ${ }^{179}$ a county bar association sought to enjoin the respondents, nonlawyers, from engaging in the unauthorized practice of law. The respondents claimed that as an ERISA-covered plan they were immune from state law under section 514 of ERISA. Employing reasoning similar to that employed by the federal district court in Bell, ${ }^{180}$ a New York Supreme Court held that the plan was not maintained by an "employee organization" within the meaning of the Act and that it was therefore subject to the rules and standards of the local bar.

The court might have reached the same conclusion on the ground that regulating what constitutes the practice of law is not preempted by ERISA because such regulation does not "relate to" employee benefit plans within the meaning of section $514 .{ }^{181}$ The scope of the "relate to" language will be discussed in the next section. It is troubling, however, that the New York court chose not to face this issue head-on, but preferred to reach the result it desired by interpreting ERISA's definition of employee benefit plan narrowly. The potential for mischief, if not major disruption of Congress's regulatory scheme, should be apparent.

IV. When Does a State Law "Relate to" an Employee Beneft Plan?

The preemptive language of section 514 of ERISA is very broad, providing, with certain exceptions, that state laws are superseded

17629 U.S.C. $\$ 1002(1)$ (1976), quoted in note 133 supra.

in See Pfenningstorf \& Kimball, supra note 7, and accompanying text.

${ }^{178}$ ERISA Op. Letter 78-04, NEBA, Inc. Pre-Paid Legal Service Plan National Employee Benefit Ass'n (Ark. Insurance Dept.) (Feb. 27, 1978) (prepaid legal service plan not an employee benefit plan within the meaning of ERISA section 3 since sponsoring entity not an "employer" or "employee organization").

17] [1978] Pens. Plan Guide (CCH) II 22,756 (N.Y. Sup. Ct. Jan. 13, 1978).

iso See text and notes at notes 154-159 supra.

${ }^{181}$ See text and note at note 184 infra. 
not only if they directly regulate an employee benefit plan, but insofar as they "relate to" such a plan. ${ }^{182}$ While on its face this terminology seems straightforward, the dimensions of remaining state authority have been the source of growing controversy. ${ }^{183}$

In one sense, defining "relate to" raises issues complementary to those involved in defining an "employee benefit plan." To ask whether a particular set of arrangements constitutes an "employee benefit plan" invites analysis of the nature of the arrangements. To ask whether a state regulation "relates to" an ERISA plan invites an inquiry into the scope of the regulation and its impact on the ERISA plan. Ultimately, however, the policy questions involved in determining whether a state law "relates to" a plan are more complex than those raised by the definition of what constitutes a "plan," and they cut more deeply into the fabric of federal-state relations. If "relate to" is interpreted broadly, consistent state regulation may become impossible in areas traditionally left to state governance, even when the state is not trying to regulate benefit plans as such, for the regulation would be preempted insofar as it happens to impose substantive requirements on an ERISA plan. ${ }^{184}$ If "relate to" is interpreted restrictively, states will be able to impose requirements on ERISA plans in the course-or in the guise-of regulating other matters, thus destroying the nationwide uniformity of the regulatory scheme established by Congress.

In recent years, as noted above, courts have hesitated to interpret congressional intent as calling for broad preemption of state law. ${ }^{185}$ Although the legislative history of ERISA reveals that Congress did intend the scope of preemption to be sweeping, courts interpreting the "relate to" language have occasionally shown more solicitude for the autonomy of states in areas traditionally left to state governance than for the integrity of ERISA, particularly when preemption seemed to require an inequitable result in the particular litigation.

\section{A. State Regulation of Substantive Benefits}

Two early decisions by Judge Renfrew of the United States

182 ERISA § 514(a), 29 U.S.C. $\$ 1144$ (a) (1976). See text and notes at notes 114-132 supra.

13s See, e.g., Sacher, ERISA Litigation, in ProceEdings of New York UnIv. ThirTIETH ANNuAl National CoNFBrRnce on LABOR 257, 263-66 (1977).

is 'In Hewlett-Packard v. Barnes, 425 F. Supp. 1294 (N.D. Cal. 1977), because such issues were not before the court in that case, a federal district court refused to respond to the suggestion that a broad construction of the "relate to" phrase in section 514 would entirely prohibit state regulation of the medical profession or hospitals, since such regulations "relate to" employee benefit plans. Id. at 1297 n.10. See note 193 infra and accompanying text.

is See text and notes at notes 102-113 supra. 
District Court for the Northern District of California interpreted the "relate to" language to hold that ERISA preempts state regulation of insurance that imposed substantive requirements directly on ERISA plans. In Hewlett-Packard Co. v. Barnes, ${ }^{186}$ Judge Renfrew held that the California Knox-Keene Health Care Service Plan Act of $1975^{187}$ was preempted under section 514 of ERISA. The KnoxKeene Act sought to promote the delivery of health care services and to ensure that participants had been well informed of the available benefits and financial position of various plans. The Act sought to accomplish this by directly regulating plans and health care services as well as providers of health insurance. It also required plans to comply with disclosure ${ }^{188}$ and funding ${ }^{189}$ requirements, and imposed standards on marketing methods ${ }^{190}$ and the quality of services provided. ${ }^{191}$ The state legislation thus imposed substantive requirements that in some instances were duplicative of the federal legislation and that generally served the same purposes as ERISA, although ERISA subjects welfare benefit plans only to reporting and fiduciary standards.

Despite the assertion by the state that the phrase "relate to" was "vague and ambiguous," Judge Renfrew concluded that it was doubtful Congress could have been any more precise. ${ }^{192}$ In a footnote he dismissed assertions by the state that the "relate to" language, if broadly construed, might preempt state regulation of the medical profession or hospitals since such laws arguably "relate to" employee benefit plans. Judge Renfrew stated that "neither the outer boundaries of ERISA's preemption provisions, nor the permissibility of Knox-Keene's regulation of health care providers, are issues before the Court in this action." ${ }^{193}$ After engaging in an extensive recitation of the legislative history of section 514, Judge Renfrew concluded that "Congress ultimately enacted Section 514(a) with the express purpose of summarily preempting state regulation of ERISA-covered employee benefit plans. That the statute, standing alone or buttressed by its legislative history, was intended to supersede state regulation of benefit plans such as plaintiffs' is indisputable."194

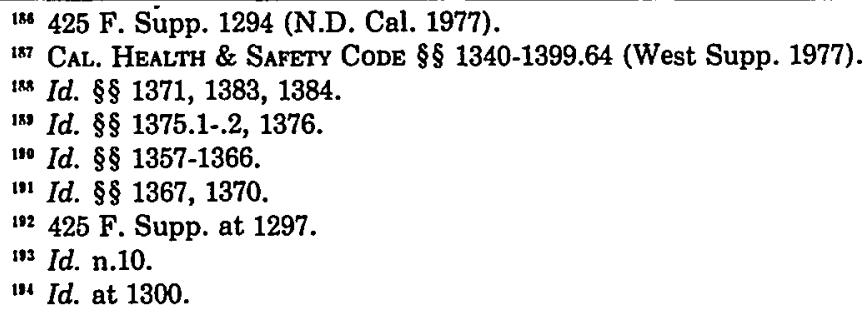


Judge Renfrew took a similar position later the same year in Standard Oil Co. v. Agsalud, ${ }^{195}$ in which Standard Oil sought declaratory and injunctive relief to prevent enforcement of the Hawaii Prepaid Health Care Act. ${ }^{198}$ Standard Oil's self-funded health benefit plan, which included participant-employees in the state of $\mathrm{Ha}$ waii, reimbursed employees and other participants for a percentage of the cost of certain health care services. The Hawaii Act required plans such as the one provided by Standard Oil, in addition to meeting the Act's reporting requirement, to include coverage for diagnosis and treatment of alcohol and drug abuse. ${ }^{197}$ After holding that the Hawaii Act was not a disability insurance law, and hence that the plan was not exempted from ERISA under section 4(b)(3), ${ }^{198}$ Judge Renfrew rejected the state's argument that only those portions of the Hawaii Act in direct conflict with ERISA were superseded and held that ERISA entirely preempted the Hawaii Act. ${ }^{199}$ Focusing on the "relate to" terminology, Judge Renfrew reaffirmed his earlier reading of the legislative history of section 514 in Hewlett-Packard as "foreclos[ing] any interpretation which would narrow its scope beyond its plain language."200

Some courts and commentators have cited Judge Renfrew's broad interpretation of section 514(a) in Hewlett-Packard as precedent for an expansive interpretation of ERISA's preemption of state laws affecting employee benefit plans. ${ }^{201}$ Other courts have

193442 F. Supp. 695 (N.D. Cal. 1977).

19 Haw. Rev. Stat. §§ 393-1 to 393-51 (1976).

17' 1976 Haw. Sess. Laws, ch. 25 (amending Haw. Rev. Stat. § 393-7(c)).

134 442 F. Supp. at 698, 706. Section 4(b)(3) of ERISA exempts from title I coverage any employee benefit plan "maintained solely for the purpose of complying with applicable workmen's compensation laws or unemployment compensation or disability insurance laws." 29 U.S.C. $\S 1003$ (b)(3) (1975). The question whether the plan was exempt under section 4(b)(3) was the principal issue in the case and most of the opinion focused on that issue. The court concluded that the Hawaii Act was not a disability insurance law based on its reading of the statutory language and legislative history and because the Hawaii Act provided a broad range of health care benefits far beyond any other state disability insurance statute. $442 \mathrm{~F}$. Supp. at 702.

is' Id. at 706-07.

2m Id. at 707.

2ot Wadsworth v. Whaland, 562 F.2d 70, 76-77, nn.34 \& 37 (1st Cir. 1977) (discussed infra at notes 262-272); Bell v. Employee Security Benefit Ass'n, 437 F. Supp. 382, 387 (D. Kan. 1977) (discussed supra at notes 154-159); National Carriers' Conference Comm. v. Heffernan, 454 F. Supp. 914 (D. Conn. 1978); National Bank of North America v. IBEW Local 3, 400 N.Y.S.2d 482, 484-85 (Sup. Ct. 1977). Other courts have followed Judge Renfrew's reasoning. See Cate v. Blue Cross \& Blue Shield of Alabama, 434 F. Supp. 1187 (E.D. Tenn. 1977); Wayne Chem. Inc. v. Columbus Agency Serv. Corp., 426 F. Supp. 316 (N.D. Ind.), rev'd on other grounds, 567 F.2d 692 (7th Cir. 1977) (discussed supra at notes 163-169); Kerbow v. Kerbow, 421 F. Supp. 1294 (N.D. Tex. 1976); Azzaro v. Harnett, 414 F. Supp. 473 (S.D.N.Y. 1976), aff'd without opinion, 553 F.2d 93 (2d Cir. 1977); see also Memorandum of the Secretary of Labor as Amicus Curiae at 10, National Carriers' Conference Comm. v. 
accepted his interpretation of the "relate to" language, but have nevertheless upheld state regulation on the ground that it was exempted from preemption by the savings clause of section $514(\mathrm{~b}),{ }^{202}$ that the plan regulated was not an "employee benefit plan," 203 or on other grounds. ${ }^{204}$ One recent case has departed from both approaches by adopting a diametrically opposed reading of the "relate to" language with respect to welfare benefit plans.

In Gast v. Oregon, ${ }^{205}$ the Oregon State Court of Appeals reversed a lower court decision that had held that ERISA superseded a state law requiring that women employees who become pregnant receive the same benefits "as other persons not so affected but similar in their ability or inability to work by reason of physical condition." 208 The court's opinion is significant both for its willingness to meet head-on the issue raised by ERISA's preemption of state regulation of welfare benefit plans and for the radical limitations it imposed on the scope of preemption under ERISA. Writing for the court, Judge Johnson did not claim that the health and benefit trust administered by plaintiffs was not an "employee benefit plan."207 He rejected the state's argument that the law requiring the provision of pregnancy benefits was a state law regulating insurance and thus not preempted by virtue of ERISA's savings clause, holding that it regulated employment practices and thus lay outside the scope of the savings clause. ${ }^{208}$

Judge Johnson focused on the fact that ERISA subjects welfare benefit plans only to reporting and fiduciary standards. He refused to infer from this a congressional intent "to cease all governmental

Heffernan, 454 F. Supp. 914 (D. Conn. 1978); Pattiz, In a Divorce or Dissolution Who Gets the Pension Rights: Domestic Relations Law and Retirement Plans, 5 Pepperdne L. Rev. 191, 231 n.181 (1978); Okin, Preemption of State Insurance Regulation by ERISA? (paper presented to ABA Section of Insurance, Negligence and Compensation Law) (January 13, 1978) at 20 (copy on file with The University of Chicago Law Review); NAIC Statement, supra note 135.

${ }^{202}$ E.g., Wadsworth v. Whaland, 562 F.2d 70 (1st Cir. 1977); Cate v. Blue Cross \& Blue Shield, 434 F. Supp. 1187 (E.D. Tenn. 1977).

${ }^{203}$ E.g., Bell v. Employee Security Benefit Ass'n, 437 F. Supp. 382 (D. Kan. 1977).

204 E.g., National Bank v. IBEW Local 3, 400 N.Y.S.2d 482 (Sup. Ct. 1977) (ERISA section 206 prohibiting assignment of beneficiary's interest does not prohibit garnishment).

20s 212 Pens. Rep. (BNA) D-11 (Or. Ct. App. Oct. 30, 1978).

${ }^{206}$ OR. Rev. Stat. $\$ 659.029$ (1977).

Senator Javits has stated that "passage of the pregnancy sex discrimination amendments . . . [Pub. L. No. 95-555, 92 Stat. 2076 (1978)] appears to have mooted the issue of preemption of State laws requiring disability plans to cover pregnancy-related leave." 125 Cong. Rec. 575 (daily ed. Jan. 24, 1979). Even if the specific issue facing the Oregon court in Gast is now mooted, the court's approach to preemption analysis under ERISA has far larger implications.

2072 Pens. Rep. (BNA) at D-13.

${ }^{203}$ Id. at D-13 to -14 . 
regulation, state or federal, other than the disclosure and fiduciary requirements of health and welfare benefits paid by employers or employee organizations." ${ }^{209}$ Rather, Judge Johnson spoke directly to the issue that has clearly most disturbed the courts.

[I]f we are to adopt the construction of 29 USC $\S$ 1144(a) advanced by plaintiffs we must import to Congress not only an intent to preempt state law, but also an intent to cease all governmental regulation, state or federal, other than the disclosure and fiduciary requirements of health and welfare benefits paid by employers or employee organizations. There is nothing in the legislative history suggesting such an intent. To the contrary, the legislative history indicates Congress was concerned with the inadequacy of governmental regulations and concluded that there should be at least minimum federal standards with respect to disclosure and fiduciary responsibility. ${ }^{210}$

Judge Johnson's view that ERISA is not concerned with the regulation of health and welfare benefit plans except to the extent it imposes reporting and fiduciary standards on them, and that state laws that impose other standards therefore do not "relate to" the ERISA plan within the meaning of section 514(a), cannot be maintained on grounds of legislative history, statutory language, or policy. Judge Johnson recognized that the broad preemptive language of section 514(a) was adopted in preference to earlier versions "which expressly restricted preemption to state laws which directly related to the specific matters regulated by ERISA."211 ERISA contains various exceptions from the scope of preemption, but nowhere does the Act suggest that employee health benefit plans are also exempt from preemption, even in part. Finally, although allowing state regulation of funding, vesting, and benefit provisions of these plans may appear to further the cause of employee protection, it would create immense difficulties for multistate plans resulting from industry-wide collective bargaining agreements or involving employees of multistate companies.

In its extreme position, Gast $v$. Oregon represents a distinct minority view, but the concerns it states openly have repeatedly influenced the courts. Even direct state regulation of substantive features of an ERISA plan may be upheld if the state's concern is not with benefit plans as such but with the implementation of a policy not logically related to benefit plans, such as the prohibition

200 Id. at D-14.

210 Id.

211 Id. at D-15. 
of gender-based employment discrimination. Thus, in Time Insurance Co. v. Department of Industry, Labor and Human Relations, ${ }^{212}$ a Wisconsin state court reached the same result as Gast-that ERISA does not preempt state law forbidding an employee disability plan from excluding benefits for pregnancy from its coverage ${ }^{213}$-although on the narrower and less principled ground that the state antidiscrimination provisions were "merely of peripheral concern"'214 to ERISA.

\section{B. Spousal Rights and Family Support}

It is where ERISA clashes with state law and court orders involving spousal rights and family support that the "relate to" language has been particularly subject to manipulation. Recently a number of cases have focused on the apparent conflict between sections 514(a) and 206(d)(1) of ERISA and various state laws or state court orders dealing with alimony, community property and other spousal rights. ${ }^{215}$ One of the first and most important, Stone $v$. Stone, ${ }^{216}$ grew out of a 1974 California divorce decree that divided the couple's marital property under the state's community property system and, as part of the division, awarded the wife a $40 \%$ interest in the husband's retirement benefits. ${ }^{217}$ The husband's alleged failure to pay this amount led his wife to institute an action against the pension plan to compel it to pay her share to her directly each month. The action raised two preemption issues: whether section 206(d)(1) of ERISA, ${ }^{218}$ which prohibits the assignment or alienation of benefits, preempts state authority to order an ERISA plan to pay benefits directly to a nonemployee spouse, and whether section

${ }^{212}$ No. 154-423 (Wis. Cir. Ct. Jan. 3, 1978). On the effect of Public Law Number 95-555, 92 Stat. 2076 (1978), see note 206 supra.

${ }^{213}$ No. 154-423, slip op. at 5.

211 Id., slip op. at 11.

${ }^{215}$ See Hutchinson, Preemption Under ERISA and State Law Spousal Rights, Nat'l L.J., Jan. 8, 1979, at 22 .

210450 F. Supp. 919 (N.D. Cal. 1978).

${ }^{217} I d$. at 920 . The number of suits seeking to attach spousal rights in pension plans has been accelerated in California by a state court opinion which held it malpractice for an attorney to fail to join in a divorce proceeding a pension plan in which one of the spouses has an interest. Smith v. Lewis, 13 Cal.3d 349, 530 P.2d 589, 118 Cal. Rptr. 621 (1974).

${ }^{218}$ ERISA section 206(d)(1) states that "[e]ach pension plan shall provide that benefits provided under the plan shall not be assigned or alienated." 29 U.S.C. $\& 1056$ (d)(1) (1976). ERISA section 206(d)(2), however, permits a voluntary assignment of up to ten percent of the pension benefit. 29 U.S.C. $\$ 1056$ (d)(2) (1976). See Wilkins v. Conroy, [1978] PENs. PlaN GuIDE (CCH) I 22,798 (N.Y. Sup. Ct. Apr. 17, 1978) (ten percent exception permits creditor attachment of pension interest in that amount); National Bank v. IBEW, id. $\mid 22,906$ (N.Y. Sup. Ct. Dec. 14, 1977) (plan ordered to pay ten percent of beneficiary's pension payment directly to judgment creditor). 
514(a) of ERISA preempts California community property laws as relating to employee benefit plans.

Judge Renfrew, who had interpreted "relate to" broadly in Hewlett-Packard ${ }^{219}$ and Standard Oil, ${ }^{220}$ read it restrictively here, ruling that there is a "narrow category of laws which affect employee benefit plans but which do not relate to them within the meaning of Section 514(a)."221 Judge Renfrew reconciled his decision that the community property laws do not "relate to" employee benefit plans (that is, are not preempted by section 514(a) of ERISA) with his earlier decision in Standard Oil-and presumably HewlettPackard-on two grounds. First, he explained that state regulation of community property is much better established than the exercise of state police powers over benefit plans, meaning not only that such regulation antedates state regulation of benefit plans, but that it involves a much more fundamental area of state concern. To allow federal preemption in this area, he wrote, would be a drastic intrusion into the balance of federal and state powers. ${ }^{222}$ Second, Judge Renfrew continued, the effect of preemption in Standard Oil still left the employee-participants free to bargain collectively for the substantive protections provided by the Hawaii Act, whereas preemption in Stone would have left the nonemployee spouse without an effective remedy. ${ }^{223}$

With respect to the other preemption issue, Judge Renfrew found no conflict between ordering an ERISA plan to pay a nonemployee spouse directly and the purposes of section 206(d)(1) because "[m]embers of the families of employees are included in the class which ERISA protects." ${ }^{224}$ In other words, section 206(d)(1) is intended to ensure that benefits will be available for financial support after retirement, but this cannot bar the claims of those whom ERISA protects. In this connection, too, Judge Renfrew emphasized that preemption by ERISA might leave the nonemployee spouse with no effective means of support if the pension benefits constituted the primary community asset and the spouse could not collect directly from the pension plan, observing that "[u]nfortunately,

211 See text and notes at notes 186-194 supra.

230 See text and notes at notes 195-200 supra.

221450 F. Supp. at 932 (emphasis added).

22 Id.

23 Id. at 932-33.

at Id. at 925. Judge Renfrew concluded that merely characterizing the nonemployee spouse's interest as a preexisting ownership right was not dispositive. To base the ruling on that rationale, he observed, would result in nonemployee spouses in states that do not recognize preexisting spousal rights in marital property being unable to collect benefits. Id. at 92526. See Pattiz, supra note 201, at 205-20. 
the refusal of spouses to honor their marital obligations after divorce is not an uncommon occurrence." 225

The opinion in Stone is open to criticism on several grounds. Judge Renfrew made no reference to the Internal Revenue Service regulations ${ }^{226}$ interpreting the assignment and alienation provisions in the Internal Revenue Code, which largely duplicate those in ERISA and would appear to prohibit the result sought by the spouse in Stone. His analysis of the "relate to" language in section 514(a) is also disappointing. In Hewlett-Packard Judge Renfrew had demurred on the necessity of locating the "outer boundaries of ERISA's preemption provisions." ${ }^{227}$ Rather than helping to locate those boundaries, Stone may have contributed to a further balkanization of preemption under ERISA. The Stone opinion does not deal directly with the broad reading of "relate to" in the Standard Oil and Hewlett-Packard decisions, but simply concludes that both California's interest in governing the disposition of marital property and justice to the nonemployee spouse necessitate permitting a direct cause of action against the plan. Asserting policy grounds for not preempting state law is not at all the same as showing that a particular state regulation does not "relate to" an ERISA plan within the meaning that Congress intended to give this language. The precision of analysis applied in Hewlett-Packard and Standard Oil is singularly lacking in Stone.

Judge Renfrew's holding that section 206(d)(1) does not bar direct actions by a nonemployee spouse against an ERISA plan because the purpose of ERISA is to protect the employee family is particularly troubling. It appears to overlook that section 206(d)(1) also protects the ERISA plan from numerous or competing claims by parties other than the plan participant. More important, to ignore the plain language of the statute on the grounds that the state regulation at issue complements the aims of ERISA and does not contradict them opens the way to far greater limitation on preemption than Judge Renfrew himself would accept. The judge's reasoning in Stone is not dissimilar to Judge Johnson's conclusion in

${ }_{225} 450 \mathrm{~F}$. Supp. at 926-27. California has now amended its divorce law to permit the joinder of employee pension plans in actions for divorce, child custody, support, and other marital settlements. CaL. Crvir. Code $\S 4351$ (West Supp. 1978). See 178 PENS. REP. (BNA) A-17 (March 6, 1978). The statutory changes conform to case law developments, particularly a decision of the California Court of Appeals permitting joinder of plans as third parties in possession of marital property. Sommers v. Sommers, 53 Cal. App. 3d 509, 126 Cal. Rptr. 220 (1975).

24 Treas. Reg. § 1.401(a)-13, T.D. 6534.

227425 F. Supp. at 1297 n.10. 
Gast $^{228}$ that state regulation of the substantive provisions of health and welfare benefits is not preempted because such regulation enhances employee protection and because the purpose of ERISA was to impose standards and not to deregulate benefit plans.

The Second Circuit, the only court of appeals to have addressed this issue, has also held that sections 514 and 206(d)(1) do not forbid garnishment of plan benefits to satisfy court-ordered family support payments. In AT\&T v. Merry, ${ }^{229}$ the Court of Appeals for the Second Circuit rejected "the unreasonable conclusion that Congress intended to preempt even those state laws that only in the most remote and peripheral manner touch upon pension plans," particularly when "that interpretation would include placing a limitation on state authority to enforce alimony and support orders." ${ }^{230}$ The court followed the reasoning of Stone, which it cited with approval. ${ }^{231}$ Merry, however, involved only alimony and child support payments, not a community property settlement. The latter, as the Supreme Court has recently recognized in Hisquierdo $v$. Hisquierdo, ${ }^{232}$ is not based on need; the rationale for finding an implied exception to ERISA's preemption provisions is weaker for community property settlements than where a court has determined that a beneficiary's wife or children need support. ${ }^{233}$

A number of other lower courts have also reached the conclusion that ERISA did not preempt state community property laws, and that section 206(d)(1) does not prohibit enforcement of a support judgment against an employee's pension benefits or deductions from such benefits of payments to be made directly as alimony or as child support. ${ }^{234}$ Moreover, the Justice Department, far from op-

25 See text at notes 205-211 supra.

2a Nos. 78-7484 \& 78-7518 (2d Cir. Jan. 29, 1979). The Second Circuit followed Merry in Cody v. Riecker, No. 78-7460 (2d Cir. Feb. 23, 1979) (involving spousal and child support orders prior to divorce).

24 Nos. 78-7484 \& 78-7518, slip op., at 1231.

2at Id., slip op., at 1231, 1233-34.

2299 S.Ct. 802, 811 (1979). See text and notes at notes 237-253 infra.

203 While community property was not at issue in $A T \& T$ v. Merry, the court of appeals distinguished Stone from Hisquierdo in a long footnote which emphasized that the Supreme Court in Hisquierdo had specifically left open the issue of whether ERISA preempted garnishment orders to satisfy community property settlements. Nos. 78-7484 \& 78-7518, slip op. at 1234 n.11 (2d Cir. Jan. 29, 1979). See text at note 251 infra.

24 E.g., Cartledge v. Miller, 457 F. Supp. 1146 (S.D.N.Y. 1978); Cody v. Riecker, 454 F, Supp. 22 (E.D.N.Y. 1978) aff'd, No. $78-7460$ (2d Cir. Feb. 23, 1979); In re Pardee, 408 F. Supp. 666 (C.D. Cal. 1976); Biles v. Biles, 216 Pens. REP. (BNA) D-1 (N.J. Sup. Ct., Oct. 2, 1978); M.H. v. J.H., 93 Misc.2d 1016, 403 N.Y.S.2d 411 (Fam. Ct. 1978); Southern Cal. IBEWNECA Pension Plan v. Superior Court, 105 Press. ReP. (BNA) D-18 (C.D. Cal. Sept. 27, 1976). See generally Wissner v. Wissner, 338 U.S. 655 (1950); Pattiz, supra note 201, at 230-41; Hardie, Pay Now or Later: Alternatives in the Disposition of Retirement Benefits on Divorce, 
posing such decisions, recently filed an amicus brief with the Second Circuit in the Merry case on behalf of the Departments of Labor and the Treasury, arguing that Congress intended an exception to section 206(d)(1) for alimony and family support orders. ${ }^{235}$

There have, however, been cases holding to the contrary. In Francis v. United Technologies Corp. ${ }^{236}$ for example, the District Court for the Northern District of California adopted an expansive reading of ERISA's preemption provision and concluded that "ERISA has pre-empted the operation of so much of California's community property laws as purport to give a non-employee spouse an interest in plan benefits." The court then held that since the spouse was neither a plan participant nor a fiduciary and had not been designated a beneficiary of the plan by her former husband, she had no standing to sue the plan for benefit payments.

The Supreme Court may have given some indication of its attitude toward spousal claims against plans covered by ERISA in its recent decision in Hisquierdo $v$. Hisquierdo, ${ }^{237}$ in which it rejected a spousal claim of a community property interest in future retirement benefits under the Railroad Retirement Act of $1974 .{ }^{238}$ Benefits under the Railroad Act are not contractual; Congress retained the right to alter or eliminate them at any time. ${ }^{239}$ Furthermore, section $231 \mathrm{~m}$ of the Act prohibits the assignment, taxation, garnishment or attachment of benefits. ${ }^{240}$ In 1975, Congress created an exception to this section and similar provisions in other federal benefit plans to permit benefits to be reached for the purpose of satisfying a legal obligation to pay child support or alimony, ${ }^{241}$ but Congress has since qualified this exception by defining "alimony" as not including claims under community property laws. ${ }^{242}$ In spite of these provi-

53 Calif. St. B.J. 106 (1978); Foster \& Freed, Spousal Rights in Retirement and Pension Benefits, 16 J. FAM. L. 187, 202-10 (1978).

225 Memorandum of the Department of Justice, Amicus Curiae, AT\&T v. Merry, Nos.

78-7484 \& 78-7518 (2d Cir. Jan. 29, 1979).

24458 F. Supp. 84, 86 (N.D. Cal. 1978). See also General Motors v. Townsend, 177 PENS.

REP. (BNA) D-1 (E.D. Mich. Feb. 27, 1978); Hutchinson, supra note 215, at 23.

2799 S.Ct. 802 (1979).

2345 U.S.C. $\S \S 231,231 a-231 t$ (1976).

2599 S.Ct. at 805.

210 Section $231 \mathrm{~m}$ provides:

Notwithstanding any other law of the United States, or of any State, territory, or the District of Columbia, no annuity or supplemental annuity shall be assignable or be subject to any tax or to garnishment, attachment, or other legal process under any circumstances whatsoever, nor shall the payment thereof be anticipated.

45 U.S.C. $\$ 231 \mathrm{~m}(1976)$

21 Social Security Act $\S 459,42$ U.S.C. $\S 659$ (1976).

212 Id. \& 462.42 U.S.C.A. \& 662(c) (Supp. 1977). 
sions, in In re Marriage of Hisquierdo ${ }^{243}$ the California Supreme Court ruled that the nonemployee spouse was not a creditor barred by section $231 \mathrm{~m}$, but a present owner of an expectancy interest in the future benefits arising from the employment of his or her spouse during marriage. ${ }^{244}$ The court did not mention the recent congressional redefinition of "alimony."

Although it reversed the decision of the California court, the Supreme Court reaffirmed the principle that family law is the province of the states. Thus, state law must do "major damage' to 'clear and substantial' federal interests before the Supremacy Clause will demand that state law be overridden."245 The Court nevertheless concluded that "California must defer to the federal statutory scheme for allocating Railroad Retirement Act benefits insofar as the terms of federal law require. The critical terms here include a specified beneficiary protected by a flat prohibition against attachment and anticipation."248 The Court thus rejected the nonemployee spouse's claim by applying a straightforward preemption analysis. Significantly for purposes of sections 514 and 206(d)(1) of ERISA, the Court refused to follow the California state courts and to focus on the question whether the nonemployee spouse was a present owner. "Such rights in the abstract" are not dispositive of the case, the Court declared, because " $[t]$ he pertinent questions are whether the right as asserted conflicts with the express terms of federal law and whether its consequences sufficiently injure the objectives of the federal program to require non-recognition."247

The Court used language in Hisquierdo that appears applicable to the interpretation of sections 514 and 206(d)(1) of ERISA. It stated that section $231 \mathrm{~m}$, "[l]ike anti-attachment provisions generally . . ensures that the benefits actually reach the beneficiary. ... It prevents the vagaries of state law from disrupting the national scheme, and guarantees a national uniformity that enhances the effectiveness of congressional policy."248 To what extent Hisquierdo indicates how the Court would deal with similar issues confronting private plans under ERISA is clouded by several fac-

21319 Cal. 3d 613, 566 P.2d 224, 139 Cal. Rptr. 590 (1977). The nonemployee spouse claimed that she was entitled to 19.6 percent of the total benefits to be received, based on half the benefits attributable to the employee spouse's labor during nearly 14 years of marriage. 99 S.Ct. at 807 .

24 In re Marriage of Hisquierdo, 19 Cal. 3d 613, 616-17, 566 P.2d 224, 226, 139 Cal. Rptr. 590,592 (1977).

24s 99 S.Ct. at 808 .

24 Id. at 809.

247 Id.

24s Id. 
tors, however. First, Hisquierdo dealt with a separate statutory structure that is substantially different from ERISA. Sections 459 and 462 of the Social Security Act expressly exclude alimony from the antialienation provision of section $231 \mathrm{~m}$ of the Railroad Act, but then expressly exclude claims under community property laws from the definition of alimony.249 The Court concluded that "Congress . . . thought that a family's need for support could justify garnishment, even though it deflected other federal benefit programs from their intended goals, but that community property claims, which are not based on need, could not do so." 250 Second, and equally important, the Court stressed that in the Railroad Act Congress provided a separate spouse's benefit that terminates upon absolute divorce. The Court explained: "Different considerations might well apply where Congress has remained silent on the subject of benefits for spouses, particularly when the pension program is a private one which federal law merely regulates." 251

Third, the Court observed that under section $231 \mathrm{~m}$ payments are not to be "anticipated." 252 The decision of the California Supreme Court would have compelled the employee spouse to pay the nonemployee spouse a lump-sum community property settlement based on benefits that may never be paid, since the employee could die before collecting benefits, thus diminishing the employee's estate, or leave the industry before retirement, thus becoming ineligible for supplemental benefits. Moreover, the Court pointed out, there is a continuing possibility that Congress might alter the Act's terms. ${ }^{253}$ It is thus unclear to what extent Hisquierdo's treatment of community property laws gives guidance to courts wrestling with community property claims arising under private plans in which benefits are vested or in pay status. It would appear, however, that the Court's reasoning in refusing to permit community property status to enforce a present interest by a nonemployee spouse in unpaid benefits applies equally to private ERISA plans. In both cases what is claimed is that the employee spouse must pay the present value of benefits that are contingent.

Equally significant is the Court's clear message that the ultimate resolution of issues of this sort is within the province of Congress. The most important precedent set by Hisquierdo may be that the Court intends to leave the policy aspects of questions of this sort

\footnotetext{
21 See text and notes at notes 241-242 supra.

$\approx 99$ S.Ct. at 811 .

251 Id. at 813 n. 24 .

22 Id. at 811.

203 Id. at 811-12.
} 
to the political branches. As discussed above with respect to multiple employer trusts, the preemption scheme established by ERISA may be in need of reform. State regulation of substantive provisions of welfare benefit plans is not desirable. Nevertheless, the scope of preemption can probably be restricted, without harming the integrity of ERISA, to allow spouses and children of plan participants to obtain the support that is due them directly from pension and similar benefit plans when the employee spouse's entitlement to the benefit is nonforfeitable and in pay status. The decision to carve out such an exception to section 206(d)(1) of ERISA should, however, be made by Congress.

\section{The Savings Clauses}

The discussion in the preceding section demonstrates that courts increasingly are narrowing the scope of preemption under ERISA by interpreting the "relate to" language of section 514(a) restrictively. The view that Congress must have intended section 514(a) to be construed narrowly where it appears to preempt state regulation of matters generally left to state governance is undermined by the succeeding clause, section $514(\mathrm{~b})$, in which Congress specifically identified areas of state legislation that were not to be preempted: state law regulating insurance, banking, or securities, ${ }^{254}$ and "generally applicable" state criminal law. ${ }^{255}$ Congress also wrote other specific exemptions from preemption into ERISA. Section 4(b)(1), ${ }^{258}$ for example, anticipated the kinds of concerns underlying the Supreme Court's decision in National League of Cities ${ }^{257}$ by exempting governmental plans from ERISA, including "a plan established or maintained for its employees by the . . . government of any State or political subdivision thereof, or by any agency or instrumentality of any of the foregoing." 258 Section 514(d) provides that Title I shall not be interpreted to "alter, amend, modify, invalidate, impair or supersede" other federal laws. ${ }^{259}$

Congress made clear that the savings clauses in section 514(b) were not to be used as devices through which states would regulate employee benefit plans as such. ${ }^{260}$ Section $514(\mathrm{~b})(2)(B)$ provides

25429 U.S.C. $\$ 1144(\mathrm{~b})(2)(\mathrm{A})(1976)$.

$2 s 5$ ERISA \& 514(b)(4), 29 U.S.C. \$ 1144(b)(4) (1976).

$2 s \mathrm{2} 29$ U.S.C. $\S 1003(\mathrm{~b})(1)$ (1976).

2si See text and notes at notes 102-106 supra.

25829 U.S.C. $\$ \S 1002(32)$, 1003(b)(1) (1976).

23529 U.S.C. $\$ 1144$ (d) (1976).

200 For example, only a "generally applicable" state criminal law is exempt. ERISA $\S$ 514(b)(4), 29 U.S.C. § 1144(b)(4) (1976). 
that a qualified "employee benefit plan" or a "trust established under such a plan" (except "plans established primarily for the purpose of providing death benefits") cannot be "deemed" an insurance company or an entity "engaged in the business of insurance or banking" for the purpose of state insurance, securities, and banking law. ${ }^{281}$ Under this exception to the savings clause, it would appear that benefit plans continue to be free of direct regulation by the state even if that regulation is part of a general body of insurance, securities, or banking law.

More problematic is the question of how far the deemer exception restricts the power of the states to impose substantive requirements on benefit plans indirectly. The language of the savings clause and the deemer exception is not a clear guide here because no single formula will respond to all the policy issues involved. It would appear that state law continues to be preempted in these areas insofar as its intent, scope, or effect relates primarily or predominantly to ERISA-covered plans and trust funds. Beyond that, a policy analysis is necessary. Apparently, Congress did not want ERISA to carve out exceptions to generally applicable state criminal law. The exceptions pertaining to insurance, securities, and banking regulations are more problematic. The following analysis suggests that the statutory purpose is best served by concluding that even indirect state regulations imposing substantive requirements on ERISA-covered plans are preempted unless the state can show that preemption would interfere significantly with the general state regulation of insurance, securities, or banking.

\section{A. Insurance Regulation}

Regulation of the insurance industry is a matter that Congress left to the states in the McCarran-Ferguson Act. ${ }^{262}$ Section 514 of ERISA continued this policy by providing both a specific savings clause for state insurance law and a savings clause for other federal laws, including the McCarran-Ferguson Act. Insurance regulation raises with particular acuteness questions about what a state may do indirectly that ERISA forbids it to do directly.

A state may, for example, indirectly protect an insured employee benefit plan by regulating underwriting and reserve policies of the insurance carrier, even if such regulation affects the cost of the plan. On the other hand, a state should not be allowed to require that an ERISA plan provide a substantive benefit by enforcing an

20129 U.S.C. $\$ 1144(b)(2)(B)(1976)$.

202 See text and note at note 138 supra. 
insurance regulation against the insurance carrier that provides the policy to the plan. Unfortunately, that is precisely what some recent cases have permitted.

Wadsworth $v$. Whaland ${ }^{283}$ involved the question whether a state statute, requiring issuers of group health policies to include coverage for treatment of mental illness, applied to a group health policy purchased by a health and welfare fund. ${ }^{264}$ The district court ruled that the New Hampshire statute was an insurance regulation and hence not preempted by ERISA. ${ }^{265}$ In affirming the lower court ruling, the First Circuit admitted that the state statute "related to" an "employee benefit plan," but held that it was saved from preemption by section $514(\mathrm{~b})(2)(\mathrm{A})$. The court rejected arguments that the state was violating the "deemer" exception to the savings clause by deeming the plan an insurance company in order to avoid federal preemption, holding, instead, that the plan was not being treated as an insurance company but as the "insured" under a group insurance policy. ${ }^{286}$

A Minnesota district court reached essentially the same result in Insurers' Action Council v. Heaton, ${ }^{287}$ when it held that the Minnesota Comprehensive Insurance Act $^{268}$ was an insurance law and not preempted by ERISA. The Minnesota Act required casualty insurers to offer state residents policies that include a specified amount of coverage, required employers to offer their employees a specific form of plan, and established a state Health Association to offer policies to those otherwise unable to obtain them. Several insurance companies and a nonprofit corporation composed of several other insurers brought suit challenging the Minnesota statute. The court denied a motion for a preliminary injunction, holding that the Act was within the savings provision of section $514(\mathrm{~b})(2)(\mathrm{A})$ of

\footnotetext{
${ }^{243} 562$ F.2d 70 (1st Cir. 1977).

2u The relevant provision of New Hampshire law provides:

Each insurer that issues or renews any policy of group or blanket accident or health insurance providing benefits for medical or hospital expenses, shall provide to each group, or to the portion of each group comprised of certificate holders of such insurance who are residents of this state and whose principal place of employment is in this state, coverage for expenses arising from the treatment of mental illnesses and emotional disorders.
}

N.H. Rev. Stat. AnN. § 415: 18-a(I) (Supp. 1977).

2as Dawson v. Whaland, 105 Pens. Plan Guide (CCH) I 23,245 (D.N.H. Feb. 11, 1977).

214 562 F.2d at 76. The court also rejected the argument that the New Hampshire law had been preempted by the National Labor Relations Act, finding that the insurance benefits were not part of the terms and conditions of the collective bargaining agreement. $562 \mathrm{~F} .2 \mathrm{~d}$ at 79. See Part VI, supra.

27723 F. Supp. 921 (D. Minn. 1976).

238 Minn. Stat. AnN. $\$ \S 62 \mathrm{E} .01-.17$ (West Supp. 1978). 
ERISA and the policy of the McCarran-Ferguson Act, preserved by section $514(\mathrm{~d})$ of ERISA. ${ }^{289}$

The district court took almost as narrow a view of the preemption doctrine as the Oregon court in Gast, ${ }^{270}$ stating that under the savings provision "the conflict between the challenged state insurance law and ERISA has to be very clear in order to trigger the preemption provision." 271 ERISA imposes only reporting and disclosure duties on health and welfare plans, the court continued, and since those requirements "have nothing to do with the substance of the insurance plans which employers must offer their employees" they are not preemptive. ${ }^{272}$ In rejecting the motion for a preliminary injunction, the court had to find that there was not even a "substantial probability" that plaintiffs could show federal preemption. This finding is open to the same criticisms as the Oregon court's in Gast, although it is based on the specific language of the savings clause rather than on a general policy analysis supporting a restrictive interpretation of the "relate to" language.

Although it was clearly the intent of Congress not to interfere in the regulation of insurance by the states, this policy was not intended to extend to permitting state regulation of the terms and conditions of employee benefit plans. That the basic definition of "employee benefit plan" in section 3(1) specifically includes plans that fund benefits "through the purchase of insurance"273 demonstrates that Congress was fully aware of the role of insurance in funding benefits when it enacted the broad preemption language in the Act. Further, the exclusion of "plans established primarily for the purpose of providing death benefits" from section $514(b)(2)(B)^{274}$ reinforces the conclusion that Congress intended to preempt state laws regulating other benefit provisions in ERISA plans even if these laws applied to all insurance policies.

The doctrinal weaknesses of Wadsworth and Insurer's Action Council are all the more serious in view of the adverse policy consequences of the decisions. If states are permitted to require employee benefit plans to provide substantive benefits under the guise of insurance regulation, the result may be a Hobson's choice for employer or labor and management negotiators: either abandon the funding of benefit plans through insurance policies or be willing to

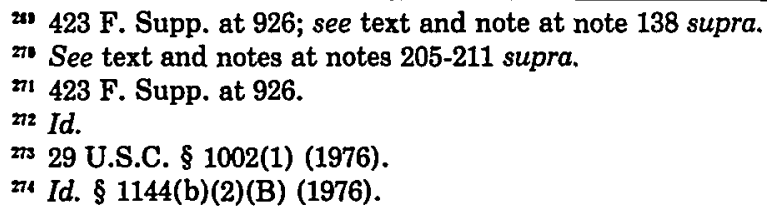


accept all-encompassing uniform national contracts. For if each state may impose its own substantive terms on the plan, the only way uniformity may be reached is by incorporating into the plan all of the benefits each state requires. This dilemma is clearly of the type that Congress sought to avoid by enacting ERISA's preemption provisions, which were formulated to relieve interstate employee benefit plans of the adverse effects of cumulative or inconsistent state regulation.

\section{B. Securities Regulation}

The savings clause for state regulation of securities ${ }^{275}$ and the "deemer" exception to it ${ }^{278}$ have not led to serious interpretive problems to date. The line separating an investment company from the management of a plan is relatively clear. An entrepreneurial enterprise does not escape regulation as an investment company merely because the assets it invests include assets of an employee benefit plan, but the management of a plan does not become subject to state regulation of trust and investment companies just because its funds are invested in securities.

The line separating a "security" from the kind of interest that employees have in most pension plans is also fairly clear, particularly after the recent decision of the Supreme Court in International Brotherhood of Teamsters $v$. Daniel. ${ }^{277}$ The Court pointed out that although Congress had been concerned that "certain interests having the characteristics of a security not be excluded from Securities Act protection simply because investors realized their return in the form of retirement benefits,"278 this did not mean "that pension benefits in and of themselves gave a transaction the characteristics of a security."279 The Court held that a pension program established under a collective bargaining agreement which requires employers to provide a compulsory noncontributory defined-benefit pension plan as part of the negotiated package of wages and benefits does not constitute an "investment contract" and that an employee's interest in such a plan does not constitute a security for purposes of the antifraud provisions of the federal securities laws.

The Court reached this conclusion by applying the test it had enunciated in SEC $v$. W.J. Howey Co. ${ }^{280}$ in 1946. First it noted that

275 ERISA § 514(b)(2)(A), 29 U.S.C. § 1144(b)(2)(A) (1976).

276 Id. \& 514(b)(2)(B), 29 U.S.C. $\$ 1144(\mathrm{~b})(2)(\mathrm{B})(1976)$.

2799 S.Ct. 790 (1979).

273 Id. at 799.

mId.

20328 U.S. 293 (1946). 
in every case finding an investment contract, "the purchaser gave up some tangible and definable consideration" in return for the interest deemed to be a security, ${ }^{281}$ while "[i]n a pension plan such as this one, by contrast, the purported investment is a relatively insignificant part of an employee's total and indivisible compensation package." ${ }^{282}$ The Court also held that an employee's interest in the plan at issue failed the "common venture" prong of the Howey test, which requires " the presence of an investment in a common venture premised on a reasonable expectation of profits to be derived from the entrepreneurial or managerial efforts of others." "283 The Court stated that although pension funds do depend "to some extent" on earnings from their assets, the greater proportion of their income derives from contributions, which are independent of the efforts of the funds' managers. ${ }^{284}$ Finally, the Court observed, what determines whether an employee's right to benefits has vested "is his own ability to meet the Fund's eligibility requirement ... rather than the Fund's investment success."285

After finding support for this position in the legislative history of the Securities Acts, the Court closed by emphasizing that "[i]f any further evidence were needed to demonstrate that pension plans of the type involved are not subject to the Securities Act, the enactment of ERISA in 1974 would put the matter to rest." ${ }^{286}$ Contrasting the protection provided by ERISA with the much more limited protection offered by the Securities Acts, the Court pointed out that "in light of ERISA it serves no general purpose" to bring noncontributory, compulsory pension plans under the Securities Acts. ${ }^{287}$

\section{Banking Regulation}

The first case decided under the savings provision for state banking law was Old Stone Bank v. Michaelson ${ }^{288}$ in which the federal district court for Rhode Island held that the Rhode Island Board of Bank Incorporation could continue to exercise authority

28199 S.Ct. at 796.

232 Id. at 797. In defined benefit plans, the Court added, the employer's payments are not accurately described as "on behalf" of any employee since there is no fixed relation between an employee's contributions and his ultimate benefits received. Id.

20 Id. (quoting United Housing Corp. v. Forman, 421 U.S. 837, 852 (1975)).

2s 99 S.Ct. at 797. Additionally, "a plan usually can count on increased employer contributions, over which the plan itself has no control, to cover shortfalls in earnings." Id. at 798 (citation omitted).

es Id. (citation omitted).

Id. at 801.

237 Id. at 802 .

2ss 439 F. Supp. 252 (D.R.I. 1977). 
under state law over the purchase of stock in a bank's parent company by the bank's employee pension benefit plan. ${ }^{289}$ Relying on Wadsworth as precedent, ${ }^{290}$ the court held that the savings provisions of section 514(b)(2)(A) made manifest the intent of Congress to permit continued state regulation of the banking business. The court ruled that notwithstanding the comprehensive scope of ERISA, "Congress did not intend that a state could not protect the depositors or shareholders of its banks in accordance with its own regulations simply because the regulated activity somehow also involved the subject matter of employee benefit plans." 291

The same difficulties implicit in Wadsworth may readily be found in Old Stone Bank. In both cases, the court construed the savings provision in a manner that permitted substantive regulation of an employee benefit plan. In Wadsworth a state was permitted to require indirectly the inclusion of a benefit; in Old Stone Bank a state was permitted to exercise control over investmentauthorization contained in the plan. Both decisions open the door to conflicting state regulation of employee benefit plans, thereby seriously undermining the uniformity of regulation envisioned by Congress in enacting ERISA.

The court in Old Stone Bank appeared most persuaded by the argument that if ERISA were held to preempt state regulation in this area, it would impair the ability of the state to control bank ownership. It would appear, however, that this state interest can be served by regulating the bank entity rather than the plan directly, although indirect regulation of the plan should also be preempted where that appears to be the dominant purpose of the regulation. The deemer exception to the savings clause indicates that Congress did not intend the state interest in bank regulation to be used as an excuse for maintaining or extending state regulation of the ordinary activities of benefit plans, including their investment decisions, even under laws "purporting to" regulate banking.

\section{State Criminal Laws}

Section 514(b)(4) of ERISA provides that "any generally applicable criminal law of a state" is not preempted by ERISA. ${ }^{292} \mathrm{Al}-$ though to date no cases have been decided under this provision, its

${ }^{230}$ Id. The state Board denied approval on the ground that the plan had been implemented before it was submitted to the Board. After denial of approval, the bank filed suit in federal court claiming that the Board at all times lacked jurisdiction over the plan.

20 See text at notes 263-266 supra.

23149 F. Supp. at 256.

2229 U.S.C. $\$ 1144(\mathrm{~b})(4)(1976)$. 
ambiguity is exacerbated by an absence of any illuminating legislative history or caselaw. Presumably, a criminal law that is "generally applicable" is one that has been enacted by a state with the intention that it apply to conduct generally rather than to an activity specifically related to employee benefit plans. For example, a state law making theft illegal would be enforceable against one accused of stealing assets from a plan, whereas a statute limited to prohibiting only thefts from employee benefit funds would not. ${ }^{293}$

The potential for uncertainty inherent in this savings provision is substantial. May a state pass a law that would otherwise be clearly preempted, such as a fiduciary standard, and by tacking on a criminal penalty and making it "generally applicable" (e.g., "all persons in a position of trust") enforce it, ERISA notwithstanding? The savings provision for state criminal laws was needed to ensure that otherwise illegal activity does not escape prosecution because a state criminal law may "relate to" an employee benefit plan. ERISA itself provides criminal sanctions for activity specifically related to employee benefit plans. Congress decided which of these activities it wished to subject to criminal sanctions and which penalties it wished to attach to these activities. ${ }^{294}$ Because Congress saved only "generally applicable" state criminal laws from preemption, it is fair to conclude that it did not want the states to subject other activities related to employee benefit plans to criminal sanctions, or to increase the sanctions that ERISA provides, unless the particular act constitutes a crime under a state law not specifically aimed at benefit plans.

\section{Preemption by Collectively-Bargained Plans}

Although the broad preemptive intent of section 514(a) may be sufficient to prohibit most state regulation of employee benefit plans, federal labor law policy may serve as another source of preemption in this area. It is well settled that Congress intended to provide for exclusive federal regulation of employee organizational activity and representative selection. ${ }^{205}$ Similarly, federal substantive law exclusively governs the collective bargaining process. ${ }^{296}$ The

${ }^{203}$ See National Carriers' Conference Comm. v. Heffernan, 454 F. Supp. 914, 915-16 (D. Conn. 1978).

20 See ERISA \& 501, 29 U.S.C. $\$ 1131$ (1976); note 84 supra.

225 Amalgamated Ass'n of Motor Coach Employees v. Lockridge, 403 U.S. 274 (1971); San Diego Bldg. Trades Council v. Garmon, 359 U.S. 236 (1959); Plankington Packing Co. v. Wisconsin Employment Relations Bd., 338 U.S. 953 (1950) rev'g per curiam, 255 Wis. 285, 38 N.W.2d 688 (1949); see Cox, Labor Law Preemption Revisited, 85 HARv. L. REv. 1337, 1339, 1368-77 (1972).

236 International Bhd. of Teamsters Local 174 v. Lucas Flour Co., 369 U.S. 95 (1962); 
Supreme Court held in Local 24, International Brotherhood of Teamsters $v$. Oliver ${ }^{207}$ that the agreement reached by the parties on "wages, hours, and other terms and conditions of employment"228 can have the force of federal law because Congress has required good faith collective bargaining over these issues in order to effectuate the national labor policy of promoting industrial peace. ${ }^{299}$ In Malone $v$. White Motor Corp., ${ }^{300}$ a case arising prior to the enactment of ERISA, ${ }^{301}$ White Motor Corporation argued from Oliver for giving a broad preemptive effect to collective-bargaining agreements.

On June 30, 1972, White Motor Corporation closed a manufacturing facility in Minneapolis, Minnesota, and terminated a pension plan it had maintained for its employees there. During the course of the litigation, in which the employees' union contended that the plan could not be terminated until the expiration of the collective bargaining agreement on May 1, 1974, the Minnesota legislature enacted the Private Pension Benefits Protection Act. ${ }^{302}$ The Minnesota Act, effective April 10, 1974, required that accrued pension benefits of employees with ten years or more service be fully funded on termination of a plan or closing of a place of employment, regardless of the vesting provisions in the collective-bargaining agreement. ${ }^{303}$ White Motor argued that since employee benefit plans have been held to be an element of "wages, hours and other conditions of employment," and hence a mandatory subject of collective bargaining, ${ }^{304}$ state law provisions, such as the Minnesota Act, that conflict with terms of a collectively-bargained employee benefit plan are superseded.

The district court denied White Motor's motion for summary judgment on the ground that Congress had intended to permit state substantive regulation of pension plans when it enacted WPPDA in

Local 24, Int'l Bhd. of Teamsters v. Oliver, 358 U.S. 283 (1959); Textile Workers v. Lincoln Mills, 353 U.S. 448 (1957); see 91 HARv. L. Rzv. 887 (1978).

23 358 U.S. 283, 296-97 (1959).

a NLRA $\S \S 8(d), 9(a), 29$ U.S.C. $\S \S 158(d), 159(a)$ (1976). These are commonly referred to as mandatory subjects of collective bargaining.

" Id. \& 1(b), 29 U.S.C. \& 141(b) (1973). See NLRB v. Burns Int'l Security Servs., Inc., 406 U.S. 272 (1972); Vaca v. Sipes, 386 U.S. 171 (1967); NLRB v. American Nat'l Ins. Co., 343 U.S. 395 (1952); NLRB v. Jones \& Laughlin Steel Corp., 301 U.S. 1, 45 (1937).

sot 412 F. Supp. 372 (D. Minn.), rev'd, 545 F.2d 599 (8th Cir. 1976), rev'd, 435 U.S. 497 (1978).

301 Since all the events took place prior to January 1, 1975, ERISA section 514(a) was inapplicable. 435 U.S. at 499 n.1.

${ }^{32}$ Private Pension Benefits Protection Act, 1974 Minn. Laws ch. 437 (codified at MnNN. Stat. ANN. \$ 181B.01-.17).

300 Minn. Stat. ANn. \& 181B.04 (West Supp. 1978).

301 Inland Steel Co. v. NLRB, 170 F.2d 247 (7th Cir. 1948), cert. denied, 336 U.S. 960 (1949). 
$1958^{305}$ and that the Minnesota Act did not operate in an area preempted by the NLRA since it did not require the inclusion of substantive terms in the collective-bargaining agreement. ${ }^{306}$ The Eighth Circuit reversed the district court's decision and held that the Minnesota Act "directly intrudes upon the employer's substantive obligations under the pension plan ... a arrived at freely through collective bargaining" ${ }^{307}$ and hence is preempted by national labor policy.

The Supreme Court reversed the Eighth Circuit by a four-tothree vote, holding that prior to the enactment of ERISA in 1974, Congress in passing the WPPDA had intended that the primary responsibility for substantive regulation of pension plans lie with the states. ${ }^{308}$ Given this reading of WPPDA's legislative history, the Court determined that it could not find that the Minnesota Act was implicitly preempted by the NLRA as affecting a collectivebargaining agreement. The Court reconciled this decision with its earlier decision in Oliver $^{309}$ by observing that Oliver had recognized exceptions to its general rule that states may not attempt to override substantive terms of a collective-bargaining agreement, including an exception for situations in which Congress has otherwise indicated that the agreement of the parties may be prohibited by state legislation..$^{310}$

The Court's decision in White Motor rests on the proposition that Congress, in enacting WPPDA, intended that the states retain authority to regulate pension plans. That policy was reversed in 1974 by ERISA. Since the legislative underpinnings of White Motor have been removed, state regulation of employee benefit plans may no longer be permissible under the NLRA in light of the congressional policy inherent in section 514 of ERISA. Since the states no longer have authority to regulate employee benefit plans under WPPDA, they have no basis to contend that such regulation generally fits within the Oliver exception to White Motor.

The practical implications of this argument are not yet clear. A reasonable argument exists that White Motor makes preemption of state regulation of employee benefit plans under the NLRA generally coextensive-but merely coextensive-with preemption under section 514 of ERISA. Under the supremacy clause, if the states

30s 412 F. Supp. at $380-81$.

304 Id. at 379.

307545 F.2d at 604.

308435 U.S. at 505-08.

305358 U.S. 283 (1959).

310435 U.S. at 512-14. 
remain free to act in the employee benefit area it is because Congress left some room for such action by not totally occupying the field or because the subject matter lies beyond the reach of Congress under the commerce clause ${ }^{311}$ or falls within the scope of the tenth amendment. ${ }^{312}$ If it is argued that Congress occupied everything it intended to occupy and that it left nothing to the states inadvertently in the benefit plan area, then the area left to the states under ERISA will be indistinguishable from that remaining under the Oliver exception upon which White Motor rests.

There may, however, be some exceptions to the general impression of coextensiveness between section 514 and NLRA preemption. For example, the Court implied in Oliver that the NLRA may not be preemptive where a provision of a collective bargaining agreement conflicts with a local health or safety regulation. ${ }^{313}$ The "health and safety" exception to Oliver remains undefined, and lower courts have applied it with varying degrees of breadth. ${ }^{314} \mathrm{~A}$ situation could arise where a state "health and safety" regulation would not be preempted by the collective bargaining agreement but would nonetheless be superseded by section 514 .

Without retreating from Congress's intent to institute broad preemption through section 514, additional arguments relying on federal labor law preemption could be marshalled to resist state law encroachments on the operation and terms of employee benefit plans that are the product of collective bargaining. While there may be few instances where NLRA preemption exceeds ERISA preemption in this area, the presence of two comprehensive federal regulatory systems should underscore Congress's intent to preempt state regulation of collectively bargained employee benefit plans. ${ }^{315}$

3il U.S. CoNST. art. I, § 8.

s2 Id., amend. X; see National League of Cities v. Usery, 462 U.S. 833 (1976); text and notes at notes 102-107 supra.

313358 U.S. at 297.

su See, e.g., Michigan Transp. Co. v. Secretary of State, 41 Mich. App. 654, 201 N.W.2d 83 (1972) (exception encompasses all proper exercises of police power); United Air Lines v. Industrial Welfare Comm'n, 211 Cal. App. 2d 729, 28 Cal. Rptr. 238, (1963) (state law prohibiting wage deductions for uniform purchases not within exception).

sis But see Wadsworth v. Whaland, 562 F.2d 70, 79 (1st Cir. 1977); Time Ins. Co. v. Department of Indus., Labor and Human Relations, No. 154-423, slip op. at 6-8 (Wis. Cir. Ct. Jan. 3, 1978). In Wadsworth, the First Circuit held that neither ERISA nor the NLRA preempted a state insurance law imposing a substantive term on an employee welfare benefit plan. See text and notes at notes 263-266 supra. The court dismissed the labor law claim with the conclusory remark that "[s]tate regulations of group insurance policies purchased by employee benefit plans are peripheral to any labor law other than ERISA." 562 F.2d at 79. 


\section{Legislative Reform}

It has been an underlying, yet recurrent theme of this article that the statutory interpretation of ERISA's preemption provisions could be distorted by the courts' perceived notions of desirable public policy. While the result-oriented focus of the courts may be understandable in cases such as Wayne Chemical, ${ }^{316}$ in which recovery by an injured innocent beneficiary may lie in the balance, it should be recognized that doctrinal confusion is an inevitable byproduct. Preemption has been a topic of recurrent concern in discussions of the implementation of ERISA and proposals for its amendment. The most efficient method of resolving the preemption dilemmas that have arisen under ERISA would be for Congress to address these concerns by more clearly articulating its intended reconciliation of federal and state power in light of practical experience under section 514 .

One matter ripe for congressional review is the impact of the Wadsworth, Old Stone Bank, and Insurers' Action Council decisions. ${ }^{317}$ The judicial construction of ERISA to permit state regulation of employee benefit plans could undermine the congressional policy of uniform national regulation. This result could be avoided by modifying section $514(\mathrm{~b})(2)(\mathrm{B})$ to provide explicitly that an employee benefit plan within the definition of ERISA may not be indirectly regulated by state insurance or banking laws that regulate another entity.

It is important that Congress, in adopting new language to prevent the imposition of substantive terms on employee benefit plans through state regulation, not allow a regulatory vacuum to arise in which entrepreneurial enterprises can flourish at the expense of the public interest. The National Association of Insurance Commissioners ("NAIC") has proposed that this be accomplished by revising the definition of "employee benefit plan" to provide more clearly which parties may properly establish such a plan. ${ }^{318}$ Similarly, the NAIC would revise the definition of "employee organization" to conform to the interpretation in Bell v. Employee Security Benefit Association ${ }^{319}$ by deleting language that includes associations organized to establish a plan, and it would revise the definition of "employer" to focus on persons that actually hire other persons to produce goods or services. ${ }^{320}$

3th 567 F.2d 692 (7th Cir. 1977). See text and notes at notes 163-169 supra.

317 See NAIC Statement, supra note 135, at 655.

318 Id. at 673-75.

311 437 F. Supp. 382 (D. Kan. 1977); see text and notes at notes 151-159 supra.

320 NAIC Statement, supra note 135, at 675-76. 
A potential deficiency in the NAIC proposal, however, is that it seeks to remedy the multiple employer trust dilemma by focusing on the establishing parties rather than on a definition of the types of plans that Congress intends to reserve for federal regulation. An alternative approach would be for Congress to define clearly the sort of employee benefit plans it wishes to be subject to ERISA, ensure that the Department of Labor and the Internal Revenue Service are given adequate substantive authority to regulate those plans, and then explicitly reserve to the states regulation of other enterprises that are more in the nature of insurance.

The "relate to" language of section 514 is more difficult to revise. Additional legislative provisions addressing preemption might create more difficulties than would be resolved, since it would be impossible to enumerate all of the potential state laws that interact with employee benefit plans or to capture them clearly in a few general provisions. Thus, a case-by-case evolution of common-law doctrine regarding the scope of "relate to" may be the only available way to alleviate this problem. Congress should reiterate, however, perhaps even in the form of an amendment, that "relate to" should be given a broad interpretation that results in preemption except in the most glaring cases in which state regulation involves prime state interests and has only peripheral impact on employee benefit plans.

If courts continue to reach decisions such as Stone, ${ }^{321}$ in which plans are subject to joinder in multitudinous personal and localized causes of action, such as divorce actions, Congress must intervene if it is to achieve its policy of uniform, national regulation of employee benefit plans. Representative John F. Seiberling of Ohio introduced a bill in 1978 to amend ERISA to provide a statutory exception to section 206(d)(1) for alimony and child support orders of state courts. ${ }^{322}$ This provision would, however, be limited in application to plan participants or beneficiaries already receiving pension benefits under a plan. Consequently, as Congressman Seiberling has explained, a court could not "use this provision to order an early payout of pension benefits to satisfy a community property settlement." 323 Enactment of this proposal would seem to be the simplest and most effective way to deal with the problem.

The danger of enmeshing plans in a maze of conflicting state

321 See text and notes at notes $216-227$ supra.

322 H.R. 13446, 95th Cong., 2d Sess. (1978).

323 Proposed Amendments to the Employee Retirement Income Security Act of 1974: Hearings on H.R. 13446 Before the Subcomm. on Private Pension Plans of the Senate Finance Comm. and the Labor Subcomm. of the Senate Human Resources Comm., 95th Cong., 2d Sess. (1978) (testimony of Rep. John F. Seiberling). 
laws and cases, resulting in the endless expenditure of plan assets in suits to which the plan is in most respects a stranger, far outweighs any minor threat to the right of the states to exclusively govern the marital relationship. Nevertheless, if policy or politics require a retreat from preemption in this area, such a retreat should be executed by congressional amendment, not by court decisions, for only in that way can uniformity be preserved while the negative impact on plans is held to a level consistent with spousal and child support rights.

The proposed ERISA Improvements Act of 1979, ${ }^{324}$ introduced by Senators Williams and Javits before the current session of Congress, ${ }^{325}$ is potentially a major step in this direction. The 1979 Bill, a refinement of a similar bill introduced by Senators Williams and Javits last year, contains provisions intended to simplify and clarify certain aspects of ERISA, ${ }^{326}$ provide plan participants with additional protection against misrepresentations, ${ }^{327}$ and consolidate administration into one new government agency. ${ }^{328}$

The 1979 Bill would help to resolve several preemption issues discussed in this article. First, it would provide that the antialienation provision of section 206(d)(1) is not to be applied to bar judgments for alimony or child support based on benefits under an ERISA plan, specifically including approvals of community property settlements "pursuant to a State domestic relations law." 329 The new provision could not, however, be applied if it would require the plan to alter its rules governing "the effective date, time, form, duration or amount of any benefit payment under the plan." ${ }^{330}$

Second, the 1979 Bill would amend section $514(\mathrm{~b})(2)(B)$ to make it clear that

[a] State insurance law which provides that a specific benefit or benefits must be provided or made available by a contract or policy of insurance issued to an employee benefit plan is a

324 S. 209, 96th Cong., 1st Sess. (1979) [hereinafter cited as 1979 Bill].

325125 CoNG. Rec. 557 (1979) (remarks of Sen. Williams); id. at 570 (remarks of Sen. Javits).

32t For example, under the 1979 Bill, supra note 324, distribution of an annual report to plan participants would no longer be required. In its stead, plan administrators could simply post notice that the report is on file and available on request. 1979 Bill, supra note $324, \S$ 113.

327 Id. $\S 154(b)$.

${ }^{32 \pi}$ Id. $\$ \S 401-404$, would assign the duties relating to employee benefit plans performed by the Department of Labor, the Internal Revenue Service, and the Pension Benefits Guaranty Corporation to a single newly-created Employee Benefits Commission.

32 Id. § 128.

sso Id. 
law which relates to an employee benefit plan within the meaning of subsection (a) and is not a law which regulates insurance within the meaning of subparagraph (A). ${ }^{331}$

The Bill provides an exception, however, for the Hawaii Prepaid Health Care Law, which was held preempted by ERISA in Standard Oil Co. v. Agslalud, ${ }^{332}$ and any other state law which is determined by the Secretary of Labor to be "substantially identical to such Hawail law." 333 The 1979 Bill proposes to preempt, in the case of such laws, only reporting and disclosure, fiduciary, and enforcment provisions that are similar to ERISA's. On the Senate floor, Senator Javits defended this exception as intended "to save Hawaii's program of mandatory employee health insurance which may be the most progressive and enlightened State program of its kind in the Nation" and "to balance the desirability of such mandatory health insurance with the Federal interest in uniformity of regulation of interstate employee benefit plans." ${ }^{334}$ The bill would give the Secretary of Labor authority to determine which plans qualify for the exemption to "permit consistent decisionmaking and avoid conflicting court decisions." 335

Third, following the Supreme Court's determination in Daniel ${ }^{336}$ that an employee's interest in a plan is not a security, the 1979 Bill would prohibit misrepresentations to employees about the terms and provisions of a plan. ${ }^{337}$ The Bill would not, however, permit recovery against the plan itself, and it would not alter ERISA's reporting and disclosure requirements. ${ }^{338}$ In addition, the Bill would expressly provide that an employee's interest in a plan is not a security for purposes of both federal and state securities law. ${ }^{339}$

The 1979 Bill does not respond to all of the preemption problems discussed above, and its proposed revisions do not parallel precisely the solutions suggested by this article. Nevertheless, by reaffirming the general proposition that congressional amendment-not sporadic and inconsistent judicial lawmaking-is the proper way to resolve these dilemmas, the Bill represents a positive development toward uniform regulation of employee benefit plans.

\footnotetext{
331 Id. § 155(1).

332 See text and notes at 195-200 supra.

3231979 Bill, supra note 324, \& 155(2).

as 125 Cong. ReC. at 575 (remarks of Sen. Javits).

ass Id.

23r See text and notes at notes 277-287 supra.

ss7 1979 Bill, supra note 324, § 154(b).

sas Id.

sos Id. $\$ 154(\mathrm{a})$.
} 


\section{CONCLUSION}

Despite the considerable attention Congress gave to the question of federal preemption when it enacted ERISA, and the sweeping preemptive language it chose to adopt, the extent of the remaining state role in regulating employee benefit plans remains a source of continuing controversy. Since one of the major aims of ERISA was to impose a uniform regulatory scheme on employee benefit plans throughout the nation, and since this aim was clearly and repeatedly expressed in Congress, line-drawing questions that are bound to arise should generally be decided in favor of preemption.

In many cases, however, courts have been moved by other policy considerations to narrow the scope of preemption, and have responded to the issues with which they have been presented by attempting to fashion rulings that force the judicial branch into a posture of making legislative decisions. Although a restriction on preemption in one particular field may not by itself undermine the effectiveness of ERISA, the restrictions discussed in this article, taken together, are not insignificant, and they may be only the tip of the iceberg of preemption problems that may arise under ERISA. Preemption has thus emerged as a fundamental area that Congress should reconsider in reviewing the implementation and performance of ERISA. 